\title{
STUDI ANALISIS POLA KOMUNIKASI INTERPERSONAL DALAM FILM SURGA YANG TAK DIRINDUKAN KARYA KUNTS AGUS TAHUN 2015
}

\section{Khoirul Muslimin, Lailiyatuzzahroh Al Jannah}

Fakultas Dakwah dan Komunikasi UNISNU Jepara

Jl. Taman Siswa (Pekeng) Tahunan Jepara

muslimin@unisnu.ac.id

\begin{abstract}
Impersonal communication is the most basic thing. Through the good impersonal communication, the relationship that tied in is good too. In "Surga yang Tak Dirindukan" movie, there are some scene that describe impersonal communication among the actors. Besides as the place of impersonal communication, "Surga yang Tak Dirindukan" contains the preaching contents that can be use for faundation of attitude and standing. The movie was released on July 2015 that directed by Kuntz Agus. The purpose of the research is to know how the pattern of impersonal communication in "Surga yang Tak Dirindukan" movie, and search the preaching contents that contained in it. The kind of the research is descriptive qualitative and semiotic data analysis of Roland Barthes type. The result of the research is the communication that used among the actors of "Surga yang Tak Dirindukan" movie. It is diadic communication (communication between two people), that happen on primer and secunder. But sometimes also use triadic communication (communication among three people). Some preaching contents that contained in it are helping someone who needs, being a good leader, being a loyal wife, being a good sincer kind mother and sincerity to yield.
\end{abstract}

Keywords : impersonal communication, preaching contents, Surga yang Tak Dirindukan 


\begin{abstract}
Abstrak
Komunikasi interpersonal merupakan hal yang paling mendasar. Melalui komunikasi interpersonal yang baik, hubungan yang terjalin pun akan baik. Dalam film "Surga yang Tak Dirindukan" terdapat beberapa scene yang menggambarakan komunikasi interpersonal antar pemain. Selain sebagai wahana komunikasi interpersonal, "Surga yang Tak Dirindukan" mengandung muatan dakwah yang dapat dijadikan landasan bersikap dan berpijak. Film tersebut dirilis pada bulan Juli 2015 yang disutradarai oleh Kuntz Agus. Tujuan penelitian ini adalah untuk mengetahui bagaimana pola komunikasi interpersonal dalam film "Surga yang Tak Dirindukan", serta menggali muatan dakwah yang terkandung didalamnya. Jenis penelitian ini adalah kualitatif yang bersifat deskriptif serta analisis data Semiotik model Roland Barthes. Hasil penelitian ini adalah komunikasi yang digunakan antar pemain "Surga yang Tak Dirindukan" adalah diadic communication (komunikasi dua orang), yang berlangsung secara primer dan sekunder. Namun, kadang pula memakai bentuk triadic communication (komunikasi tiga orang). Beberapa pesan dakwah yang terkandung didalamnya, yaitu menolong orang yang membutuhkan, menjadi imam yang baik, menjadi istri yang setia, menjadi ibu yang baik, ikhlas, baik hati dan kebesaran hati untuk mengalah.
\end{abstract}

Kata kunci : Komunikasi Interpersonal, Pesan Dakwah, Surga yang Tak Dirindukan

\section{A. PENDAHULUAN}

Film merupakan suatu karya, media efektif untuk pembelajaran dan pengajaran. Dalam suatu film, tak terlepas oleh adanya proses komunikasi baik antar tokoh maupun penulis terhadap khalayak. sebagaimana komunikasi, film memiliki peran edukatif, informatif, persuasif dan rekreatif.

Dunia perfilman terus berkembang dari waktu ke waktu. Bisnis perfilman pun kian bertambah besar, karena minat masyarakat akan film kian hari kian besar (Malaki, 2004:116). Film merupakan media audio visual, oleh karena itu pesan yang terkandung di dalamnya lebih mudah diserap oleh masyarakat dibandingkan dengan media lainnya. Masyarakat dapat menikmati tayangan film secara mendalam, sehingga secara tidak langsung masyarakat telah mengambil pelajaran dari setiap tayangan film tersebut.
Film telah menjadi bagian kehidupan sehari-hari kita dalam banyak hal, bahkan cara kita bicara sangat dipengaruhi oleh metafora film. Skenario pribadi terentang dalam urutan flashback, percakapan dan peran. Kita mendekat, memilah-milah, lalu menghilang. Karena adanya pengaruh film yang sebagian riil dan sebagian tidak, maka penting untuk mengetahui tentang industri yang membuatnya (Vivian, 2008:160).

Lebaran tahun 2015 dunia perfilman merilis sebuah film bernuansa religi berjudul "Surga yang Tak Dirindukan", diangkat dari sebuah novel karya Asma Nadia dengan judul yang serupa. Film yang disutradarai Kuntz Agus ini berhasil mencapai kesuksesannya. Di bulan pertama, film ini telah ditonton sekitar 1.523.700 penonton (movie.co.id, 10/12). Berkat pencapaian tersebut, film "Surga yang Tak Dirindukan" memenangkan penghargaan 
Box Office Movie Award (IBOMA) 2016 hingga Piala Antemas 2016 di puncak peringatan Hari Film Nasional sebagai film terlaris 2015 (cinemags.id, 15/12).

Film ini bercerita mengenai kehidupan rumah tangga Arini dan Pras, yang mencoba membangun surga dunia yang mereka impikan melalui kejujuran dan kebersamaan. Namun, ujian menghampiri tatkala Meirose datang. Kemunculan Meirose telah menodai kepercayaan Arini kepada Pras. Dongeng ber-ending bahagia yang Arini impikan telah hancur oleh keputusan Pras menikahi Meirose. Kekecewaan harus diterima Arini, tatkala ia harus berbagi suami, cinta dan perhatian dengan orang lain.

Komunikasi yang kurang baik antara Arini dan Pras telah membuat kehidupan rumah tangga mereka hancur. Pras yang begitu saja menikahi Meirose secara diamdiam telah menciptakan rahasia besar dalam keluarganya. Namun, sedalamdalamnya mengubur bangkai, akan tercium juga. Arini yang mengetahui pras telah membagi cintanya, mendadak sakit, rapuh dan kecewa. Bagaimana mungkin suami yang selama ini ia banggakan telah membohonginya. Namun, dengan adanya pengertian, rasa cinta dan sayang Arini pun memaaafkan Pras, suaminya.

Komunikasi interpersonal merupakan salah satu bentuk komunikasi yang berarti proses komunikasi yang berlangsung dua orang atau lebih secara tatap muka, yang memungkinkan setiap pesertanya menangkap reaksi orang lain secara langsung, baik verbal maupun non verbal (Mulyana, 1999:15).
Kemampuan komunikasi interpersonal adalah hal yang paling mendasar. Adanya perbedaan pendapat, konflik serta pertikaian merupakan wujud kesalahfahaman berkomunikasi. Seperti hal nya kisah Arini dan Pras dalam film "Surga yang Tak Dirindukan" karya Kuntz Agus. Ketidak jujuran Pras atas pernikahan keduanya kepada Arini telah membuat prahara besar dalam rumah tangganya. Pras yang menikahi Meirose atas dasar menolong menuntut Arini untuk bisa ikhlas berbagi suami dengan Meirose, tanpa ada komunikasi sebelumnya.

Kemampuan komunikasi interpersonal diperlukan manusia untuk menunjang segala aktifitas dan kegiatannya agar lancar. Komunikasi yang baik dapat mempengaruhi persepsi seseorang maupun orang lain. Dalam tayangan film "Surga yang Tak Dirindukan", terdapat beberapa scene yang menggambarkan pola komunikasi interpersonal antar tokoh, yang dikupas dalam penelitian ini.

Alasan penulis tertarik untuk menjadikan film "Surga yang Tak Dirindukan" sebagai subyek dalam penelitian ini karena film tersebut mengandung nilai-nilai keagamaan yang cukup bagus untuk dikupas lebih lanjut, ceritanya sederhana, alur cerita yang menarik, kisah yang menyentuh jiwa sehingga mampu membawa penonton seakan-akan mengalami hal tersebut.

Oleh karena itu, penulis ingin mengkaji pola komunikasi interpersonal yang dimuat dalam film indonesia yaitu "Surga yang Tak Dirindukan" yang disutradarai Kuntz Agus hasil karya tulis Asma Nadia dengan judul Studi Analisis 
Pola Komunikasi Interpersonal dalam Film "Surga yang Tak Dirindukan" Karya Kuntz Agus Tahun 2015.

Bertitik tolak dari latar belakang pemikiran di atas, ada dua pokok permasalahan yang dibahas, yaitu: Bagaimana komunikasi interpersonal dalam film “Surga yang Tak Dirindukan”? dan apa saja pesan dakwah yang terkandung dalam film "Surga yang Tak Dirindukan"?

\section{B. METODE PENELITIAN}

Bodgan dan taylor dalam Basrowi (2008:21) mendefinisikan metodologi kualitatif sebagai prosedur penelitian yang menghasilkan data deskriptif berupa katakata tertulis atau lisan dari orang-orang dan perilaku yang diamati. Menurut mereka, pendekatan ini diarahkan pada latar dan individu tersebut secara holistik (utuh). Jadi, dalam hal ini tidak boleh mengisolasikan individu atau organisasi ke dalam variabel atau hipotesis, tetapi perlu memandangnya sebagai bagian dari suatu keutuhan.

Subjek penelitian disini adalah film "Surga yang Tak Dirindukan" yang disutradarai oleh Kuntz Agus. Sedangkan Objek penelitiannnya adalah pola komunikasi interpersonal antar tokoh dalam film Indonesia "Surga yang Tak Dirindukan".

Data primer adalah data yang diperlukan dalam melakukan penelitian atau istilah lain dari data utama. Dalam penelitian ini, data utama yang digunakan adalah film "Surga yang Tak Dirindukan" karya Kuntz Agus yang rilis pada tahun 2015. Data sekunder adalah data pendukung yang fungsinya sebagai pelengkap atas data primer. Dalam penelitian ini, data sekunder yang digunakan adalah referensi yang berkaitan dengan penelitian ini, berupa buku-buku, kumpulan skripsi, internet, serta dokumen-dokumen yang dapat dijadikan bahan rujukan penulisan skripsi sebagai faktor pendukung.

Penelitian ini menggunakan studi kepustakaan. Studi ini, dilakukan untuk mendapatkan landasan teori yang diperlukan berdasarkan buku-buku atau literatur yang terkait dengan penelitian skripsi ini. Dengan memanfaatkan perpustakaan, yang berarti dengan melakukan penelusuran kepustakaan dan menelaahnya. Studi kepustakaan dalam penelitian ini adalah dengan menggali data yang berhubungan dengan komunikasi interpersonal dan film "Surga yang Tak Dirindukan", mengambil serta mengamati dari beberapa skripsi dan buku-buku yang berhubungan dengan penelitian ini.

Penelitian ini menggunakan analisis semiotika, yaitu ilmu yang mempelajari simbol dan tanda. Simbol dan tanda tidak hanya terdapat dalam bahasa, tetapi juga dalam bentuk lain, seperti kebudayaan, ritual, gambar, seni dan lainnya. Semiotika digunakan untuk menganalisis bagaimana tanda dan simbol disepakati dan digunakan bersama serta bagaimana keterkaitannya. Dalam penelitian ini, peneliti menggunakan analisis semiotik model Roland Barthes, yang mengembangkan dua tingkatan penandaan yang disebut dengan denotasi dan konotasi.

Denotasi merupakan sistem penandaan tingkat pertama (first- order signification) yang terdiri dari hubungan antara penanda (signifier) dan petanda 
(signified) dengan realitas eksternal yang ada di sekitarnya. Konotasi adalah sistem penandaan tingkat kedua (second-order signification), di mana penanda dan petanda pada tingkat denotasi menjadi penanda untuk petanda yang ada di wilayah-wilayah budaya.

\section{Tabel 1}

Sistem penandaan Roland Barthes

\begin{tabular}{|c|c|}
\hline $\begin{array}{ll}\text { 1. Signifier } & \text { 2. } \\
\text { (Penanda) } & \text { (Petanda) }\end{array}$ & \\
\hline $\begin{array}{l}\text { 3. Denotatif Sign } \\
\text { (Tanda Denotatif) }\end{array}$ & \\
\hline $\begin{array}{l}\text { 4. Connotatif Signifier } \\
\text { (Penanda Konotatif) }\end{array}$ & $\begin{array}{l}\text { 5. ComnotatifSignified } \\
\text { (Petanda Konotatif) }\end{array}$ \\
\hline \multicolumn{2}{|c|}{ ConnotatifSign } \\
\hline
\end{tabular}

Berdasarkan peta tanda Roland Barthes diatas, terlihat bahwa tanda denotatif (3), terdiri atas penanda (1) dan petanda (2). Akan tetapi, saat bersamaan, tanda denotatif juga penanda konotatif (4). Dalam konsep Roland Barthes, tanda konotatif tidak sekedar memiliki makna tambahan, namun juga mengandung kedua bagian makna denotatif yang melandasi keberadaannya. Denotasi adalah apa yang digambarkan tanda pada suatu objek, sedangkan konotasi adalah bagaimana menggambarkan tanda pada suatu objek.

Berikut adalah tabel untuk mempermudah memahami tanda-tanda dalam film, dari sistem denotasi, konotasi, dan makna:

\section{Tabel 2}

Denotasi, konotasi dan makna

\begin{tabular}{|c|c|c|}
\hline Denotasi & Konotasi & Makna \\
\hline $\begin{array}{l}\text { Narasi/dialog } \\
\text { maupun } \\
\text { pendeskripsian } \\
\text { adegan yang } \\
\text { mengindikasikan } \\
\text { adanya } \\
\text { komunikasi } \\
\text { interpersonal } \\
\text { antar pemain. }\end{array}$ & $\begin{array}{c}\text { Interprestasi } \\
\text { peneliti } \\
\text { dengan cara } \\
\text { menjelaskan } \\
\text { maksud dari } \\
\text { narasi/dialog } \\
\text { maupun } \\
\text { adegan } \\
\text { pemain. }\end{array}$ & $\begin{array}{c}\text { Penyebutan } \\
\text { atau penamaan } \\
\text { sikap, yang } \\
\text { mendeskripsikan } \\
\text { pola komunikasi } \\
\text { interpersonal, } \\
\text { seperti apakah } \\
\text { dialog dan } \\
\text { adegan yang } \\
\text { diteliti tersebut. }\end{array}$ \\
\hline
\end{tabular}

Analisis pola komunikasi interpersonal dalam penelitian ini akan diidentifikasi berdasarkan tanda-tanda yang terdapat daam film "Surga yang Tak Dirindukan" untuk mengetahui makna yang terkandung dalam film tersebut, baik tersirat maupun tersurat. Tanda yang dimaksud disini adalah tanda verbal ataupun non verbal. Penelitian ini akan mencoba mengulas bagaimana pola komunikasi interpersonal dalam film "Surga yang Tak Dirindukan" berdasarkan komunikasi yang terjadi antar pemain dengan menggunakan analisis semiotik metode Roland Barthes.

Beberapa tahapan dalam menganalisis data dalam penelitian ini, yaitu:

a. Mengamati film "Surga yang Tak Dirindukan" dengan memutar film tersebut, sekaligus mengidentifikasi data dan mengelompokkannya. Data tersebut berupa adegan dan dialog dalam scene film yang menggambarkan komunikasi interpersonal.

b. Setelah data terkumpul, langkah selanjutnya adalah mengkaji isi film dengan menafsirkan makna dari dialog 
dan adegan dengan menggunakan teori yang sudah ada.

c. Langkah terakhir adalah penarikan kesimpulan dari penelitian yang telah dilakukan berupa data deskriptif.

\section{HASIL DAN PEMBAHASAN}

\section{Sinopsis Film "Surga yang Tak Dirindukan"}

Film "Surga yang Tak Dirindukan" merupakan sebuah film karya sutradara Kuntz Agus yang terinspirasi dari sebuah novel karya tulis Asma Nadia dengan judul yang serupa. Film ini bercerita mengenai kehidupan rumah tangga Arini (Laudya ChinTya Bella) dan Prasetya (Fedi Nuril) yang diimpikan layaknya dongeng Cinderella yang happy ending.

Pertemuan atas dasar ketidaksengajaan membawa mereka pada istana cinta. Kisah cinta pada pandangan pertama mengantarkan Arini dan Pras untuk mengikat janji suci pernikahan atas nama cinta. Kebahagiaan bertambah tatkala Nadia (Sandrinna Michelle) hadir sebagai pelengkap kehidupan bahagia mereka.

Pras merupakan sosok yang ideal di mata Arini. Baik, setia dan mencintai keluarga. Dengan kebersamaan dan kepercayaan, keharmonisan mereka dapatkan dalam mengarungi bahtera rumah tangga. Kepercayaan Arini kepada Pras begitu kuat, hingga berbagai isu perselingkuhan yang melibatkan teman dekatnya, Lia (Vitta Mariana) tak mengusik sedikitpun dari rasa percayanya kepada Pras, suaminya.

Namun, cinta mereka harus diuji tatkala Meirose (Raline Shah) datang.
Seorang perempuan yang merenggut kebahagian Arini, menjadi orang ketiga dalam pernikahannya. Meirose, perempuan yang dinikahi oleh Pras atas dasar menolong, telah membawa duri dalam rumah tangga Arini dan Pras yang telah dibangun sejak lama.

Saat perjalanan menuju kantor, Pras melihat sebuah kecelakaan mobil yang jatuh ke jurang. Dengan sigap, Pras menolong korban kecelakaan tersebut dan alangkah kagetnya, saat ia mengetahui bahwa korban tersebut adalah seorang perempuan dalam balutan baju pengantin. Perempuan tersebut adalah Meirose, seorang calon pengantin yang dikhianati oleh kekasihnya, meninggalkan Meirose begitu saja dalam keadaan mengandung janin tujuh bulan.

Akibat kecelakaan yang terjadi, Meirose mengalami koma, sementara Akbar, bayinya lahir dalam keadaan selamat. Selama Meirose koma, Akbar berada dalam penjagaan Pras, sebagaimana anaknya sendiri. Setelah sadar, tak disangka Meirose melakukan percobaan bunuh diri dengan melompat dari ketinggian, namun hal tersebut berhasil diketahui Pras. Pras mengingat masa lalunya, ditinggalkan seorang ibu karena kecelakaan, sehingga dari masa kanak-kanak ia telah menjadi yatim piatu. Masa lalu tersebut secara tidak sengaja membawa keyakinan kepada Pras, menikahi Meirose atas dasar menolong, mempertahankan nyawa seseorang agar bisa terus hidup bersama keluarganya.

Pernikahan kedua Pras tersebut membawa dilema baginya, bagaimana mungkin ia menceritakan hal itu kepada Arini, istri yang dicintainya. Namun disisi 
lain, kebahagiaan datang dari Meirose, mendapat seorang suami sekaligus ayah yang baik bagi anaknya Akbar, meski ia tahu bahwa ia bukanlah satu-satunya perempuan yang ada di kehidupan Pras.

Rahasia Pras atas pernikahan keduanya dengan Meirose pun akhirnya diketahui Arini. Seketika Arini rapuh, istana dongeng yang selama ini ia impikan runtuh bersamaan keputusan Pras memadu cintanya. Tangisan kekecewaan menemani, namun Arini harus tetap tersenyum dihadapan Nadia, anak semata wayangnya.

Untuk memastikan keyakinannya, Arini mendatangi Meirose, perempuan yang ia anggap sebagai pengahancur surga dunianya. Dalam pertemuan mereka, Meirose menceritakan kisah hidupnya. Hidup sebatang kara, hanya ditemani seorang Asisten Rumah Tangga, serta ditinggalkan calon suaminya saat pesta pernikahan sedang berlangsung. Arini tertegun, namun sekali lagi, ia merasa bahwa dirinyalah yang menjadi korban dalam masalah ini.

Pasrah atas apa yang terjadi kepada dirinya, membuat Arini sedikit merasa tenang, ditambah wejangan sang ibu untuk bisa ikhlas menerima takdir Tuhan, mengingat bahwa ayahnya semasa hidup juga melakukan hal yang sama, membagi cinta ibunya dengan orang lain, tanpa sepengetahuan Arini. Lambat laun, Arini ikhlas menerima keadannya, mengizinkan Pras mengurusi Akbar yang sedang sakit, meski saat itu Nadia, anak kandung Pras tengah mengikuti pertunjukan mendongeng.
Kerukunan terjadi antara Meirose dan Arini, terlihat saat mereka menjenguk Pras yang saat itu berada di Rumah Sakit karena menolong seseorang dari jambret. Tak disangka, Meirose yang sebelumnya mengurai rambut panjangnya, kini telah menutupinya dengan hijab. Nadia pun menyambut Akbar, adiknya dengan senang hati.

Usai sembuh dari sakitnya, Pras memboyong Meirose dan Akbar ke rumahnya, tempat tinggal yang selama ini ia singgahi bersama Arini dan Nadia. Keikhlasan Arini telah membuat segala hal yang buruk dipikirannya menjadi hal yang positif. Menerima keluarga keduanya sebagai keluarga barunya. "Siapa yang bisa menjamin orang itu baik atau tidak kalau bukan kita sendiri yang mempercayainya".

Diakhir kisah, Meirose pergi. Meninggalkan Pras, Arini serta Akbar anaknya. Dengan keikhlasan dan kebesaran hatinya, ia melangkah mundur, membiarkan dongeng Arini berlanjut bahagia, meski ia tahu dongengnya akan berakhir dengan kesendirian dan kesedihan. Namun, ia rela. Baginya, kebahagiaannya adalah ketika Pras dan Arini bahagia.

\section{Unsur Komunikasi Interpersonal}

Unsur komunikasi merupakan halhal yang harus ada dalam komunikasi interpersonal. Terdapat perbedaan pendapat dari beberapa ahli mengenai unsur dalam komunikasi interpersonal. Menurut Jalaluddin Rakhmat (2009:49-67), unsur komunikasi interpersonal adalah sensasi, persepsi, memori dan berpikir. Menurutnya pula, keempat unsur tersebut 
harus ada dan tidak boleh tertinggal dalam proses komunikasi interpersonal.

Unsur-unsur tersebut tergambarkan dalam cuplikan tayangan film "Surga yang Tak Dirindukan". Dari saat komunikator menyampaikan pesan atau informasi kepada komunikan, si komunikan mencerna pesan atau informasi, dilanjut penyimpanan pesan atau informasi oleh komunikan hingga tindak lanjut komunikan atas pesan atau informasi yang telah ia terima.

\section{Gambar 1}

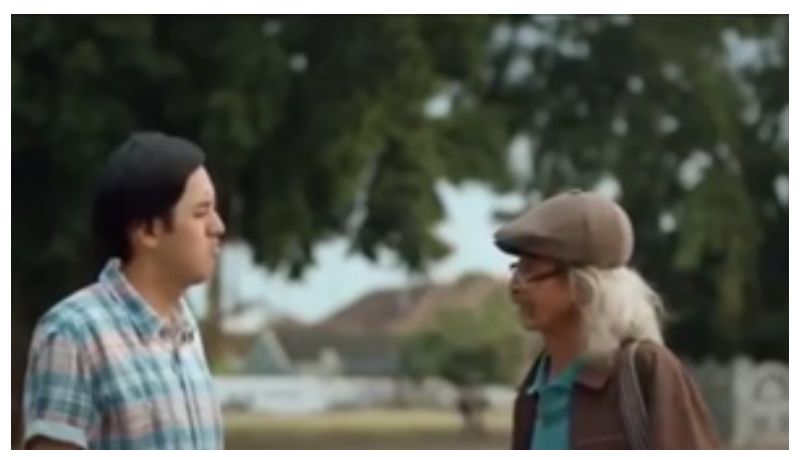

"Masjid Nurul Huda Bantul masih jauh pak?" Tanya Amran kepada seorang Bapak. Lantas Bapak itu menjawab, "Tidak. Gak ada 5 KM. Sampean ngidol aja, nanti ketemu panggung Krapyak, kandang Manjangan namanya. Nah, nanti ngidol lagi. Udah deket dari situ. Nanti tanya aja orang disana." Amran menimpali "Matur suwun Bapak". Lalu Bapak tersebut menjawab, "Nggeh".

Kutipan film di atas menggambarkan adanya komunikasi interpersonal antara Amran (Kemal Palevi) dengan seorang Bapak separuh baya. Dalam percakapan tersebut, Amran bertanya tentang sebuah alamat, mengingat Jogjakarta bukanlah tempat tinggalnya, akan tetapi ke Jogja sebagai bagian dari tanggungjawab kerjanya.
Unsur komunikasi interpersonal telah nampak dalam percakapan tersebut, yakni terdiri antara dua orang, terdapat informasi yang disampaikan oleh komunikator (yang ditanya) serta kepahaman komunikan (yang bertanya) atas informasi yang didapat.

Meski mereka belum pernah mengenal sebelumnya, akan tetapi komunikasi harus dilakukan dengan baik, mengingat Amran adalah pendatang baru yang memerlukan sebuah bantuan. Dari percakapan tersebut, telah terjadi komunikasi interpersonal yang baik, terbukti ketika Bapak tersebut menjawab pertanyaan Amran dengan baik.

Secara semiotik, komunikasi interpersonal di atas adalah denotasi, karena mendeskripsikan adegan telah mengindikasikan adanya komunikasi interpersonal, tanpa perlu adanya interprestasi dari peneliti.

Salah satu jenis komunikasi yang frekuensinya terjadi cukup tinggi adalah komunikasi interpersonal. Oleh karena frekuensinya yang cukup tinggi, tidak mengherakan apabila banyak orang menganggap bahwa komunikasi interpersonal mudah dilakukan, semudah orang makan dan minum (Suranto, 2011:3).

\section{Gambar 2}

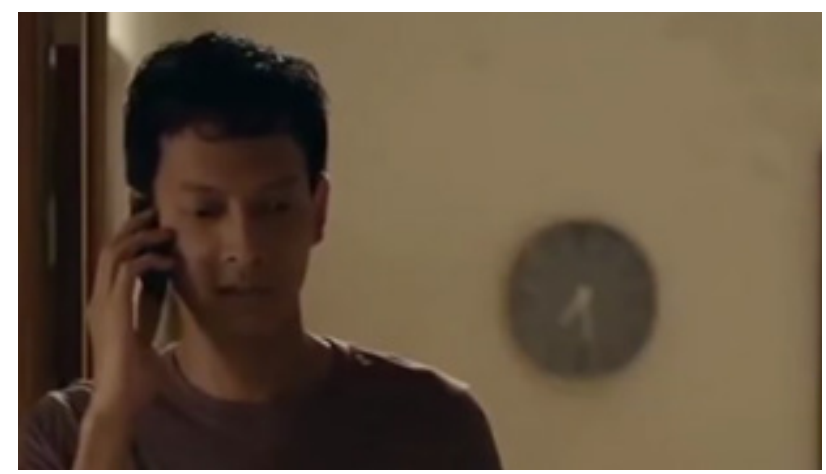


"Assalamu'alaikum", salam Arini. "Wa'alaikumsalam. apa kabar Arini?", jawab Pras. Arini menjawab, "Alhamdulillah aku baik. Kamu gimana mas?". Pras menjawab, "Aku baik, alhamdulillah. Gimana kabar Hasbi?". Arini menimpali, "Hasbi alhamdulillah sudah sehat. Dia sudah bisa lari-lari tho. Dia sekarang sudah menjadi asistenku, kemana-mana bawa boneka". "Kamu kenapa suka banget mendongeng?", tanya Pras pada Arini. "Dongeng itu sedekah aku mas. Dengan mendongeng, aku nitipin ilmu pada anak-anak", jawab Arini. "Kamu cerdas dan puitis", ucap Pras pada Arini. Dengan tersenyum, Arini menjawab "Mas Pras bisa aja".

Cuplikan film tersebut ketika Pras untuk pertama kalinya menelpon Arini, wanita yang telah membuatnya jatuh cinta pandangan pertama. Dalam percakapan tersebut, keduanya saling bertanya kabar, kesukaan serta keseharian mereka masingmasing. Arini merasa terenyuh, ketika Pras menceritakan kesendiriannya, yatim piatu sejak kecil dan hidup di panti asuhan.

Bagi Arini, mendongeng adalah sedekahnya. Dengan mendongeng, ia dapat menitipkan ilmu kepada anak-anak didiknya secara tidak langsung. Mendengar pengakuan Arini, Pras seketika memuji Arini dengan berkata bahwa Arini adalah perempuan yang cerdas dan puitis. Dari hubungan yang sekejap namun serius, Pras memantapkan diri untuk memilih Arini sebagai calon Ibu dari anak-anaknya kelak.

Meski komunikasi tersebut terjadi tidak langsung (face to face) melainkan melalui telpon, namun komunikasi tersebut dianggap sebagai komunikasi interpersonal, sebagaimana pendapat Richard L. Weaver. Menurutnya, kehadiran fisik dalam berkomunikasi tidaklah terlalu penting, karena komunikasi sebelumnya telah terbentuk dan adanya saling pengertian antar individu (Bungin, 2014:32).

Sebagaimana unsur komunikasi yang mengikutsertakan media sebagai bagiannya. Sehingga, telpon merupakan salah satu media untuk dapat berkomunikasi dengan sesseorang, terlebih jika orang tersebut berada pada cakupan wilayah yang sulit dijangkau.

\section{Gambar 3}

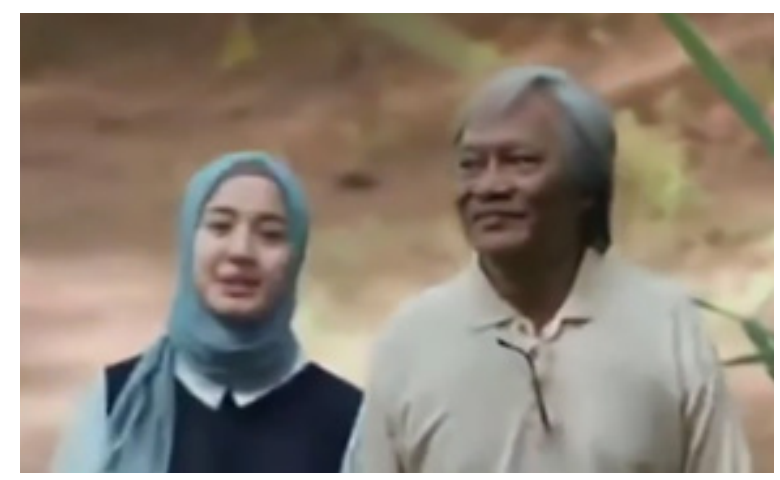

"Rin, kamu serius dengan anak Solo itu?", tanya ayah Arini. "Maksud Bapak mas Pras?", jawab Arini. "Huum. Kamu yakin dia bisa menjadi imam yang baik buat kamu?" tambah ayah Arini. Dengan sedikit jeda, Arini menjawab, "Siapa sih yang dapat menjamin baik buruknya seseorang pak, kalau bukan kita yang mempercayainya". Ayah Arini seketika menimpali, "Dan, kamu percaya sama dia?". Arini menjawab, "Atas ridho Bapak".

Secara nyata, telah terjadi kontak komunikasi interpersonal antara Arini dengan ayahnya (Landung Simatupang). Terdiri dari dua orang serta terdapat pesan yang tersampaikan. Dalam percakapan tersebut, ayah bertanya kepada Arini mengenai keyakinannya menerima pinangan Pras, orang yang baru saja 
dikenalnya. Tanpa ragu Arini menjawab" Siapa sih pak yang dapat menilai baik buruknya seseorang? Kalau bukan kita sendiri yang mempercayainya," Jawaban bijak Arini itu pun mengundang senyum ayahnya seraya memeluk Arini dengan rona wajah bahagia.

Komunikasi interpersonal yang baik telah membuahkan hubungan yang baik pula, terbukti dengan kedekatan Arini dan ayahnya. Kemantapan jawaban Arini telah memantapkan pula hati ayahnya, untuk menyerahkan Arini kepada Pras, calon suaminya.

Menurut William C. Schutz dalam Arni Muhammad (2014:161) terdapat tiga kebutuhan interpersonal yang didapat melalui komunikasi interpersonal, yaitu kebutuhan akan kasih sayang, kebutuhan diikutsertakan, dan kebutuhan akan kekuasaan atau kontrol.

\section{Gambar 4}

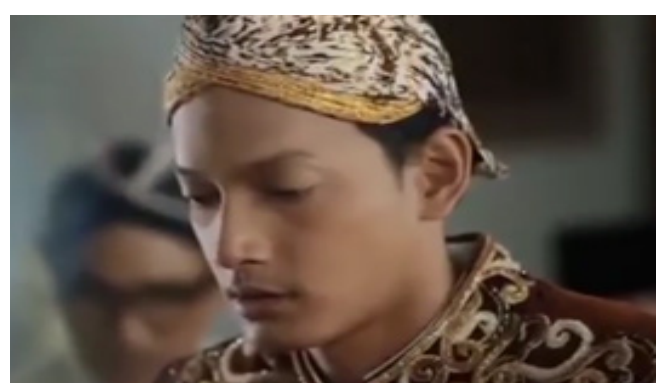

"Terima kasih Arini, sudah percaya sama aku. Tidak ada yang bisa aku berikan untuk membahagiakanmu, kecuali diriku sendiri", ucap Pras dalam Narasi. "Buat aku, kebahagiaan tidak diberikan mas, tapi bersama-sama kita ciptakan dengan saling percaya. Disitulah surga kita mas", timpal Arini. "InsyaAllah, aku akan menjaganya bersamamu", tambah Pras. "Amin", jawab Arini.
Cuplikan gambar tersebut ketika usainya ijab kabul Pras dan Arini. Dalam narasi, terjadi komunikasi antara Pras dan Arini.Ucapanterima kasih Praskepada Arini atas kepercayaannya menjadi pendamping hidupnya. Dalam narasi tersebut, Pras berkata bahwa ia tidak bisa memberikan kebahagian apa-apa kepada Arini, kecuali diri Pras sendiri. Bagi Arini, kebahagian bukanlah sesuatu yang diberikan. Akan tetapi, sama-sama menciptakan saling percaya, disitulah surga cinta.

Kepercayaan dan keyakinan telah membuat segalanya menjadi indah. Kepercayaan Pras memilih Arini, dan keyakinan Arinimendampingi Pras. Dengan keyakinan, segala hal yang tabu menjadi layak, dan dengan kepercayan segala hal yang lemah bisa menjadi kuat. Dengan keyakinan dan kepercayaan, keindahan bagai surga dunia akan tergenggam.

Secara analitik, cuplikan tersebut merupakan kontak komunikasi interpersonal, meski tidak langsung lewat lisan. Namun, narasi tersebut telah menggambarkan adanya komunikasi antara Arini dan Pras, ibarat dari hati ke hati.

Semiotik menurut pandangan Roland Barthes terbagi dalam dua bagian, yaitu denotasi dan konotasi. Denotasi secara singkat diartikan sebagai yang tampak, dan konotasi berarti hal yang masih perlu diinterprestasikan. Untuk cuplikan gambar di atas, konotasi menjadi hal yang pas diterapkan, mengingat komunikasi tersebut tidak nampak, namun masih memerlukan interprestasi dan penjelasan narasi. 
Pras yang telah resmi menjadi suami Arini berjanji untuk selalu berusaha membahagiakan dan menjaga Arini, terlihat ketika ia mengamini doa dan harapan Arini. Masa lalunya yang lara menguatkannya menjadi sosok yang bertanggungjawab dan lemah lembut.

\section{Gambar 5}

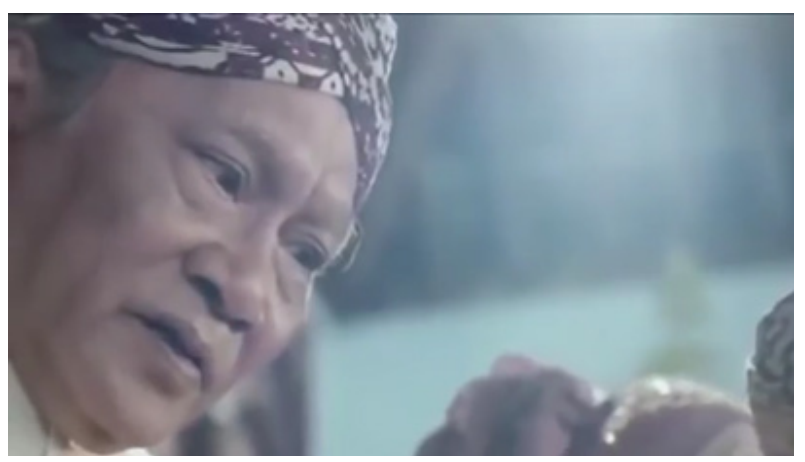

"Jangan pernah sakiti Arini", pesan ayah Arini kepada Pras. Dengan menganggukkan kepala, Pras menjawab, "Iya".

Scene tersebut saat Pras sungkem kepada mertuanya, ayah Arini. Sudah menjadi tradisi jawa setelah ijab kabul, sepasang prngantin baru sungkem kepada orang tua dan mertua sebagai bentuk bakti dan tunduk seseorang. Ketika sungkem, ayah Arini berpesan untuk tidak menyakiti Arini, menjaganya sebaik yang Pras bisa, melepaskan tanggungjawab yang selama ini ia emban kepada suaminya, Pras. Ketika seorang perempuan telah menikah, maka seluruh tanggungjawab dibebankan kepada sang suami, sebagai imam dan nahkoda dalam mengarungi bahtera rumah tangga.

Ayah Arini sebagai komunikator dan Pras sebagai komunikan. Dalam proses komunikasi tersebut, telah adanya pesan yang dikirim, yaitu pesan untuk tidak menyakiti Arini. Feedback atas pesan tersebut adalah anggukan kepala dari Pras, sebagai tanda bahwa ia menyetujui permintaan mertuanya, untuk tidak menyakiti Arini.

Hal yang lumrah tatkala seorang ayah berpesan demikian, manakala seorang anak yang biasanya dielus-elus dalam buaian kasih sayang, akan pergi meninggalkan orang tua. Setiap orang tua pasti ingin anaknya bahagia, meski tak selamanya hidup itu indah. Karena kecintaan dan ketulusan Pras, ia berjanji pada dirinya dan dihadapan mertuanya, untuk menjaga Arini, tidak menyakitinya.

Komunikasi diadik dapat bersifat sebagai interaksi intim dan longgar. Interaksi intim ditandai oleh adanya kedekatan hubungan kedua belah pihak yaitu dengan adanya ikatan emosional yang kuat diantara keduanya. Interaksi yang bersifat longgar dkarenakan yang menjadi ikatan interaksi itu semata-mata kebutuhan fungsional, tidak ada ikatan emosional (Suranto, 2011:18).

\section{Gambar 6}

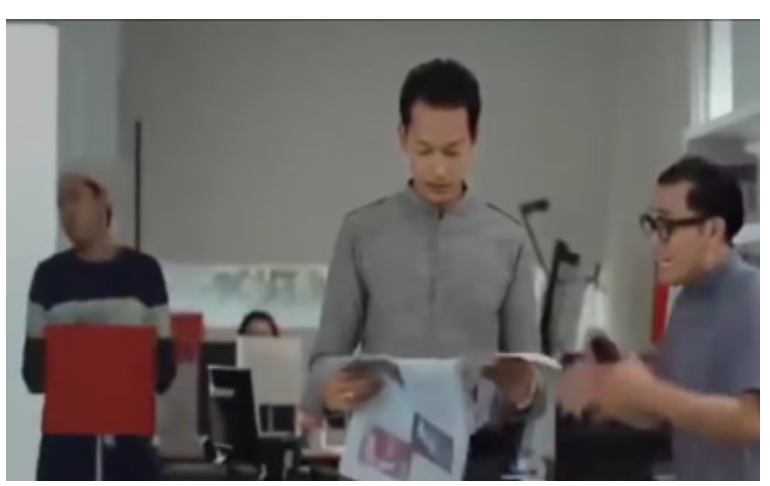

"Pras, ini tuh duitnya gede, bisa buat operasional kita setahun ke depan kenapa sih loe", ucap Hartono. "Har, kalau mall itu dibangun, radius 5 KM pasar tradisional disana bakalan mati. Pedagang-pedagang kecil itu bakalan kehilangan pendapatan", tangkis Pras. "Pras, kita tuh arsitek, bukan badan sosial. Buat apa kita mikirin orang 
miskin. Kalau tiba-tiba negeri ini miskin, bakal jadi apa, jadi tanggung jawab kita juga?", jawab Hartono. "Seenggaknya, kalau kita gak bisa nyelesain masalah, jangan memperparah", pungkas Pras.

Perdebatan kadang terjadi karena adanya perbedaan pendapat, pandangan dan keputusan antara beberapa pihak. Namun, perdebatan ini akan terselesaikan dengan baik jika menggunakan bahasa komunikasi yang baik pula. Perdebatan terjadi antara Pras dan Hartono (Tanta Ginting) karena perbedaan pendapat. Hartono ingin mengambil proyek pembangunan Mall, namun Pras sebaliknya.

Pras menolak, karena pembangunan tersebut tidak jauh dari pasar tradisional, sehingga memungkinkan para pedagang kecil kehilangan pendapatannya.

Komunikasi yang kurang baik akan berujung pula dengan hubungan interpersonal yang kurang baik pula. Samasama mempertahankan ego tanpa ada yang merendahkan suara, bisa jadi akan menjadi sebuah pertengkaran. Namun, segala sesuatu akan menjadi baik jika ada komunikasi yang baik pula. "Setidaknya, jika tak mampu menyelesaikan masalah, jangan memperparah". Kutipan dialog Pras sebagai bentuk respond atas pernyataan sahabatnya, Hartono.

Pada hakikatnya pola hubungan interpersonal merupakan sebuah siklus, dari perkenalan, menuju kebersamaan, menuju perpisahan, kembali rujuk, menuju kebersamaan lagi, dan seterusnya. Pada setiap tahap dalam suatu hubungan interpersonal, komunikasi memainkan peran yang berbeda (Suranto, 2011:41).

\section{Klasifikasi Komunikasi Interpersonal}

Menurut Arni Muhammad (2013:159), klasifikasi komunikasi interpersonal ada tiga yaitu interaksi intim, percakapan sosial, interogasi atau pemeriksaan dan wawancara. Secara singkat, interaksi intim terjadi antara seseorang dengan orang yang memiliki ikatan emosional yang kuat, seperti sahabat dekat, keluarga, suami/ istri dan sanak famili. Percakapan sosial hanya sebatas komunikasi sederhana, tidak terlalu mendalam layaknya interaksi intim. Selanjutnya interogasi atau pemeriksaan adalah komunikasi dalam lingkup resmi, dan wawancara adalah tanya jawab untuk mendapat sebuah informasi.

Setiap komunikasi interpersonal pastinya memiliki klasifikasi yang berbedabeda, karena perbedaan komunikator dan komunikan. Secara tersurat, klasifikasi komunikas interpersonal dapat dimengerti dengan mudah.

\section{Gambar 7}

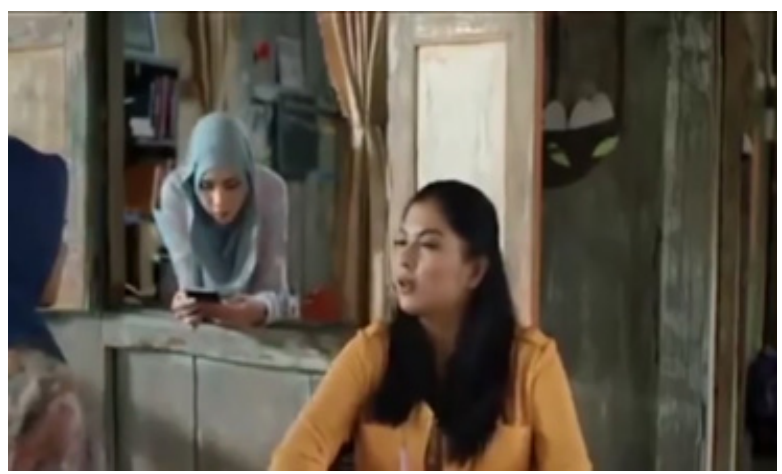

"Kamu kenapa Li?", tanya Arini pada Lia. "Aku mau tuntut cerai mas Ivan", jawab Lia. "MasyaAllah, memangnya kenapa?", Arini bertanya lagi. "Nih, coba kamu lihat. Menurut kamu aku sebagai istri gimana baca sms itu?", jawab Lia sambil menyodorkan Hp nya pada Arini. "Setiap aku tanya, selalu aja alasan katanya Hp nya dipinjem sama 
temennya. Masuk akal gak?", tambah Lia. "Kamu udah ngajak mas Ivan ngomong baikbaik belum?" saran Arini. "Ngomong apa? Ini sudah jelas-jelas ada buktinya", bantah Lia. "Siapa tahu Hpnya emang dipenjem?", ucap Sita.

Terjadi komunikasi interpersonal yang terdiri dari tiga orang, yaitu Arini (Laudya Chintya Bella), Sita (Zaskia Adya Mecca) dan Lia (Vitta Mariana) yang disebut the triad. Komunikasi interpersonal dapat terjadi oleh lebih dua orang, karena dalam komunikasi interpersonal paling sedikit melibatkan dua orang (Bungin, 2014:32).

Komunikasi yang terdiri dari tiga orang disebut sebagai triadic communication, dimana satu orang sebagai komunikator dan dua orang sebagai komunikan. Dalam cuplikan gambar tersebut, Lia sebagai komunikator dan Sita serta Arini sebagai komunikan. Bila dibandingkan antara triadic communication (komunikasi tiga orang) dengan diadic comunication (komunikasi dua orang), diadic communication lebih efektif, karena perhatian komunikator terpusat pada satu komunikan saja, sehingga mampu menguasai frame of reference komunikan sepenuhnya.

Arini, Sita dan Lia merupakan sahabat dekat, sehingga apapun keluh kesah yang mereka rasakan, tumpahan kesedihan akan mereka bagi bersama. Lia, seorang Ibu dari satu orang anak menganggap bahwa suaminya tidak setia lagi. Menganggap telah mengkhianati cinta dan kesetiannya, lantaran menemukan isi pesan handphondnya berisi kata-kata mesra. Dengan nada tersedu, Lia mengungkap bahwa ia ingin bercerai dengan suaminya. Namun, Arini menyarankannya untuk meminta tabayyun (penjelasan) kepada suaminya, bisa jadi itu hanyalah sebuah kesalahpahaman.

Menurut Julia T. Wood (2013:185) dalam bukunya "Komunikasi Teori dan Praktik" mengemukakan mengenai persahabatan stabil, yaitu ketika temanteman merasa stabil pada kehidupan satu sama lain. Persahabatan stabil terintegrasi ke dalam konteks sosial yang lebih besar dari kehidupan teman, sehingga mereka menjadi bagian dari jaringan sosial keseluruhan. Patokan dari tahapan ini adalah asumsi adanya keberlanjutan dan kepercayaan. Dalam pertemanan Arini, Lia dan Sita terdapat keterbukaan dan kepercayaan, apa yang mereka keluhkan mengenai kehidupan pribadi masing-masing, akan tercurahkan kepada ketiganya.

Secara tersurat komunikasi yang terjalin antara Arini, Sita dan Lia merupakan interaksi intim, karena mereka memiliki ikatan emosional yang kuat. Ketika satu orang merasakan kesedihan, yang lain pun ikut merasakakannya, bagai satu tubuh. Komunikasi yang mereka bangun sangat baik, karena memahami situasi dan kondisi yang sedang terjadi. Ketika Lia sedang menggebu-gebu dengan kemarahannya, Arini dan Sita tetap diam tenang, tanpa menggurui atau mencampuri pandanganpandangan Lia mengenai suaminya. 


\section{Gambar 8}

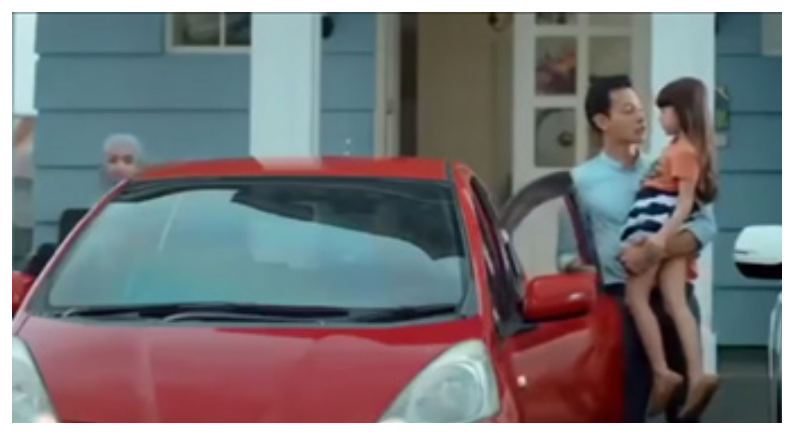

"Ayah kok gak ikutan? Ntar Nadia mau dongeng bareng eyangkung", tanya Nadia pada Pras. "Maaf tuan putri. Ayah harus ke Kulon Progo, nengok jembatan ayah disana. Nanti ayah nyusul hari sabtu ya", jawab Pras.

Keintiman terjadi antara Pras dan anaknya, Nadia. Kecintaanya kepada keluarga membuat rumah tangganya harmonis, tentu dengan adanya rasa saling percaya. Dalam gambar tersebut, tampak Pras sedang menggendong Nadia, buah hatinya bersama Arini. Saat itu, Pras mengantakan Nadia masuk mobil untuk pergi ke rumah neneknya, ayah (Sutedja) dan Ibu Arini (Sulastri). Saat itu, Pras tidak bisa mendampingi Arini dan Nadia, karena ia akan ke Kulon Progo mengunjungi proyek jembatannya.

Pras merupakan seorang arsitektur, bersama dengan dua rekannya, Hartono dan Amran. Sebagai leader Pras memiliki kewenangan untuk menerima atau menolak proyek yang ditawarkan, sebagai contoh pembangunan Mall. Pras tetap bersikukuh untuk tak menerimanya, karena pertimbangan tempat yang masih berada di area pasar tradisional.

Hasil penelitian menunjukkan bahwa kemampuan meningkatkan manfaat komunikasi antar-pribadi merupakan suatu keahlian istimewa, tidak hanya bagi pengembangan pribadi dan keluarga, akan tetapi juga bagi peningkatan karir (Riswandi, 2009:22).

\section{Gambar 9}

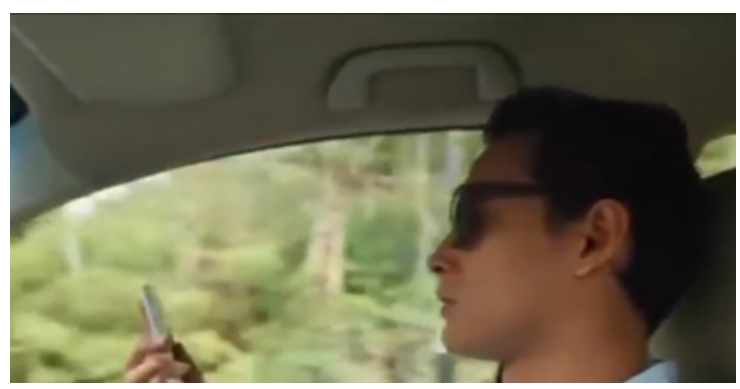

"Ya udah deh, aku sekarang menuju kesana. Kamu urus bag...", ucap Pras saat di telpon Amran.

Komunikasi interpersonal dapat melalui media, seperti handphone, karena dalam karakteristiknya, komunikasi interpersonal tidak harus berada pada tempat yang sama, tidak harus tatap muka (face to face).

Komunikasi interpersonal dua orang dapat terjadi secara primer maupun sekunder. Apabila pihak-pihak yang mengadakan komunikasi dapat langsung bertemu dan berhadapan muka, hal itu dikataan bersifat primer. Sedangkan apabila dalam kontak itu diperlukan suatu perantara yang berupa orang-perorangan atau media, dikatakan kontak tersebut bersifat sekunder (Suranto, 2011:18). Dalam komunikasi Pras tersebut, sifat komunikasi interpersonal tersebut adalah sekunder, karena melalui media perantara.

Komunikasi interpersonal merupakan yang paling efektif dalam mengubah sikap, pendapat dan perilaku seseorang, karena 
sifatnya yang dialogis berupa percakapan. Arus balik bersifat langsung, komunikator mengetahui tanggapan komunikan ketika itu juga (Effendy, 2003:30).

Komunikasi interpersonal merupakan proses pengiriman pesan dari seseorang kepada orang lain atau beberapa orang, baik secara verbal maupun non-verbal yang ditanggapi orang lain dan merupakan interaksi antara pribadi-pribadi yang terlibat secara utuh dan langsung satu sama lain dalam menyampaikan maupun menerima pesan secara nyata.

Hakikatnya,

komunikasi interpersonal terjadi karena setiap manusia membutuhkan manusia lain untuk berinteraksi, sebagai upaya memenuhi kebutuhan dan bekerjasama dengan orang lain. Dengan kerjasama, akan tercipta kesatuan komunikasi yang efektif.

Gambar 10

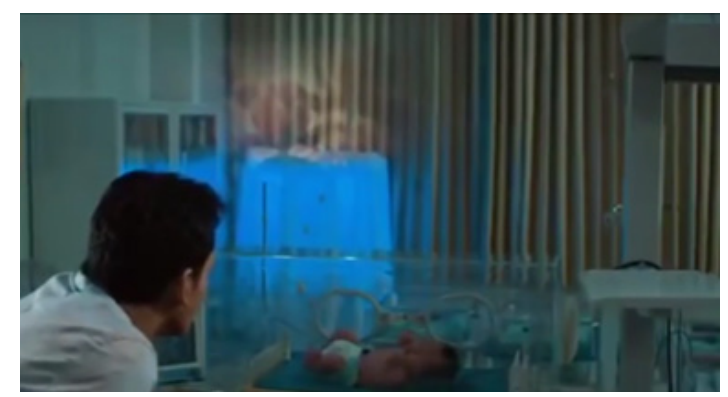

"Kamu harus kuat, kamu harus menjadi orang besar", ucap Pras pada Akbar.

Bayi Meirose, perempuan yang ditolong Pras saat kecelakaan mobil. Dengan lembut, menyapa Akbar sesaat setelah ia dilahirkan. Akbar Muhammad merupakan nama yang diberikan Pras, saat ditanya dokter mengenai nama bayi. Telah terjadi kontak sederhana antara Pras dan Akbar, saat Pras berkata bahwa Akbar harus kuat, menjadi orang besar sebagaimana namanya.

Salah satu tujuan komunikasi interpersonal adalah membantu. Dengan adanya komunikasi interpersonal, dapat membantu orang lain. Misalnya, psikiater dengan pasien. Dengan bercerita mengenai keluhan pasien, psikiater dapat membantu mengahadapi masalahnya, memberikan solusi yang tepat untuk sang pasien.

Gambar 11

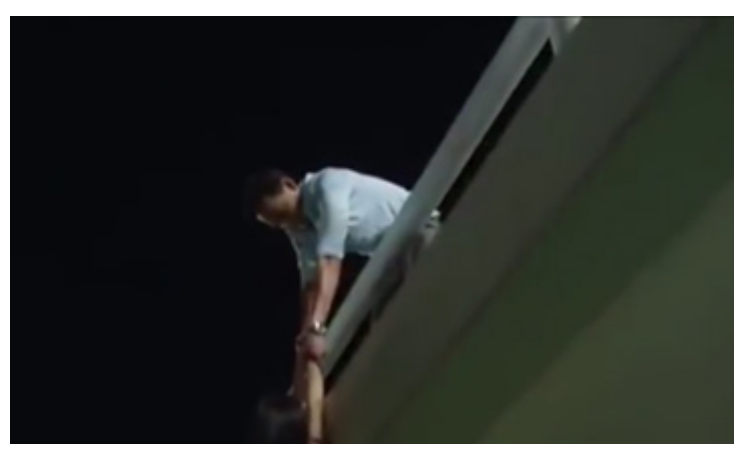

"Demi Allah, aku akan menikahimu, aku janji", ucap Pras pada Meirose. "Bohong", ungkap Meirose tak percaya. Untuk meyakinkan, Pras kembali berucap, "Demi Allah, aku akan menikahimu, sekarang".

Setiap individu memiliki kepribadian yang berbeda, termasuk dalam hal penyelesaian masalah. Ada yang bersikap santai, acuh, emosi bahkan melakukan suatu hal yang membahayakan dirinya sendiri. Meirose, perempuan yang dikhianati calon suaminya, pergi saat pesta pernikahan sedang berlangsung. Berasal dari keluarga broken home, membuat pribadi Meirose serasa terguncang, jauh dari kasih sayang orang tua.

Kejadian yang menimpanya membuat Meirose tidak dapat berpikir jernih. Usai melahirkan Akbar, Meirose berniat mengakhiri hidupnya. Untungnya, Pras 
tiba tepat waktu. Dengan sigap, Pras mengingatkan bahwa ada Akbar yang membutuhkan Meirose, namun Meirose acuh. Kesedihannya sudah tak terbendung lagi. Semua kesedihannya dikarenakan satu, laki-laki. Sejak peristiwa yang terjadi dengannya, Meirose seakan sudah tak percaya lagi dengan laki-laki.

Saat Meirose meloncat dari ketinggian, Pras menolongnya, memegang tangan Meirose dengan kuat dan menariknya ke atas. Masa kecil Pras yang ditinggalkan Ibunya, melintas dipikirannya. Seketika, ia yakin bahwa harus menolong Meirose, meski harus dengan menyakiti Arini. "Demi Allah, aku akan menikahimu", ucap Pras saat itu. Pernikahan atas dasar menolong telah menyelamatkan jiwa Meirose, namun menyakiti hati Arini.

Pernikahan kedua Pras dilakukan secara diam-diam, hanya mengundang dua teman dekatnya, Hartono dan Amran. Keputusannya memadu Arini telah menjadi prahara besar dalam rumah tangganya, namun Pras berpikir bahwa memang itu yang harus ia lakukan, menikahi Meirose untuk menyelamatkan dan menyembuhkan jiwanya.

Memiliki latar belakang yang sama, ditinggalkan oleh orang tua, membuat Pras memberikan perhatian lebih kepada Meirose. Bersikap lemah lembut dan baik hati, layaknya ia bersikap kepada Arini. Menganggap Akbar sebagai anak kandungnya, tanpa memperhatikan asal usulnya.

Komunikasi interpersonal Pras telah membantu hidup Meirose, melupakan masa lalu kelamnya dengan menjalani hidup yang baru. Secara tidak langsung, komunikasi interpersonal pun telah membantu Meirose saat ia akan bunuh diri. Saat itu, Pras berkata bahwa tempat Meirose berdiri saat itu setinggi 19,5 M. Jika beratnya hanya 50-55 Kg, ketika jatuh, ia tidak mati tapi akan cacat. Mungkin, beberapa kalimat Pras tersebut sedikit mengagetkan Meirose, dilihat dari raut mukanya yang terhenyak.

Terdapat dua jenis kecakapan yang harus dimiliki seseorang agar mampu berkomunikasi interpersonal dengan baik dan benar, yaitu meliputi kecakapan kognitif dan behavioral. Kecapakan kognitif adalah kecapakapan tingkat pemahaman mengenai cara mencapai tujuan personal maupun relasional, sedangkan behavioral adalah kecakapan berkomunikasi pada tingkat tindakan, mengarahkan pelaku komunikasi untuk mencapai tujuan personal maupun relasional.

Sesuai gambar, Pras memiliki dua kecakapan komunikasi tersebut, yaitu kognitif dan behavioral. Kecakapan kognitif saat Pras memberikan pemahaman kepada Meirose, dan behavioral saat Pras menarik tangan Meirose saat meloncot dari ketinggian.

Gambar 12

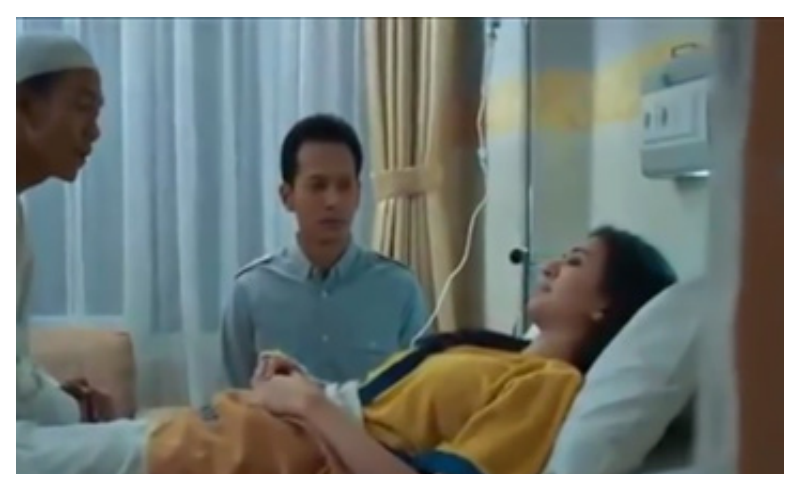


"Asyhadu an laa ilaaha illallah, wa asyhadu anna muhammadarrasulullah", ucap Meirose sebagai tanda masuknya ia ke dalam agama islam.

Sebelum melangsungkan pernikahan, Meirose membaca dua syahadat, sebagai bukti bahwa kini ia seorang muallaf. Sungguh, pernikahan telah membuatnya menjadi orang yang mendapatkan hidayah. Lewat Pras, hidayah itu datang.

Atas dasar empati, Pras mampu memberikan motivasi dan secercah harapan kepada Meirose. Menuntun Meirose ke arah yang benar, meninggalkan kehidupan gelapnya sebelum bertemu Pras.

Mampu berinteraksi dengan orang lain merupakan anugerah terindah, meski kadang terdapat kendala dalam berkomunikasi. Menjadi suatu permasalahan tatkala komunikasi interpersonal mempertemukan dua orang yang memiliki perbedaan karakter, sifat dan sikap, sehingga menimbulkan situasi yang kurang nyaman.

Gambar 13

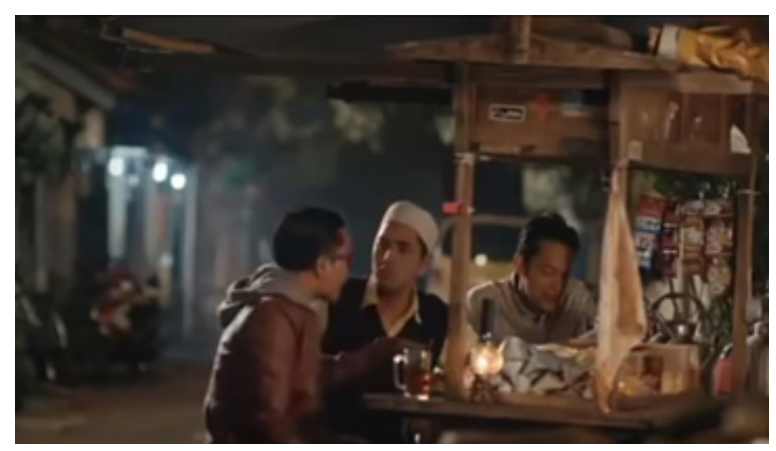

"Gila loe Pras, gila. Kenapa loe harus..", ungkap Hartono. "Gue ngerti Har", jawab Pras lesu. "Sssttt Har, sudah, gak usah didebat. Pras itu gak salah, nih, coba ente baca surat an-nisa'. Dan jika kamu takut berlaku adil, menikahi perempuan yatim, maka nikahilah wanita yang kamu senangi, dua, tiga atau empat. Nih, baca nih surat An-Nisa", bela Amran pada Pras. "Eeh, ente kalau baca ayat, jangan setengah-setengah dong, baca juga berikutnya. Dan jika takut tidak bisa berlaku adil, maka nikahilah satu wanita saja", balas Hartono atas argumen Amran.

Terjadi komunikasi triadik antara Pras, Hartono dan Amran. Pras sebagai komunikator, dan Hartono serta Amran sebagai komunikan. Pernikahan kedua Pras menimbulkan pertentangan dari Hartono. Ia tidak setuju dengan keputusan yang Pras ambil, menikahi seseorang yang belum pernah ia kenal dan tanpa sepengetahuan Arini. Di sisi lain, Amran sepakat dengan keputusan Pras, atas dasar surat AnNisa:129, bahwa boleh seorang laki-laki menikahi perempuan lebih dari satu. Namun, tangkisan dari Hartono datang, saat ia berkata bahwa seseorang tersebut haruslah bisa berlaku adil.

Seseorang memiliki karakter dan cara komunikasi yang berbeda, dan hal tersebut yangterjadiantara Pras, Hartonodan Amran. Hal tersebut sering menjadi penghambat terjalinnya komunikasi yang efektif, karena emosional dari masing-masing individu dapat memperburuk proses komunikasi. Ketidaksatuan pandangan mengenai poligami yag dilakukan Pras, membuat sedikit pertengkaran antara ia dan Hartono. Namun untuk memecah suasana, Pras berkeyakinan bahwa ia menikahi Meirose atas dasar menolong, menyelamatkan jiwa seseorang. Bagi Pras, apa yang telah dilakukannya adalah tanggungjawab pribadinya dengan Allah SWT.

Komunikasi interpersonal dapat membentuk hubungan yang baik dengan 
seseorang, jika proses komunikasi bersifat terarah. Hubungan yang kurang harmonis dapat diperbaki dengan komunikasi. Meski Pras dan Hartono sering berbeda pendapat, namun ikatan emosional mereka kuat, sehingga apapun yang telah mereka hadapi, tak memupus tali persahabatan mereka.

Efektifitas komunikasi interpersonal merupakan interaksi antara dua individu atau lebih yang saling menukar informasi dan saling mempengaruhi, sehingga dapat memperoleh umpan balik secara langsung demi tercapainya suatu tujuan.

Kualitas umum dari efektifitas komunikasi interpersonal salah satunya adalah keterbukaan (opennes), kesediaan diri mengungkapkan informasi yang ditutupi dan disembunyikan. Pras bersifat terbuka kepada dua sahabatnya atas pernikahan keduanya dengan Meirose, mengindikasikan bahwa telah terjadi komunikasi yang efektif dan klasifikasi interaksi intim antara ketiganya.

Komunikasi yang efektif ditandai dengan hubungan atau emosional yang baik. Kegagalan komunikasi terjadi ketika isi pesan tersampaikan, namun hubungan personal rusak. Ketidaksatuan pendapat dan konflik harus dilihat sebagai upaya memahami perbedaan yang ada tanpa meninggikan ego masing-masing.

Gambar 14

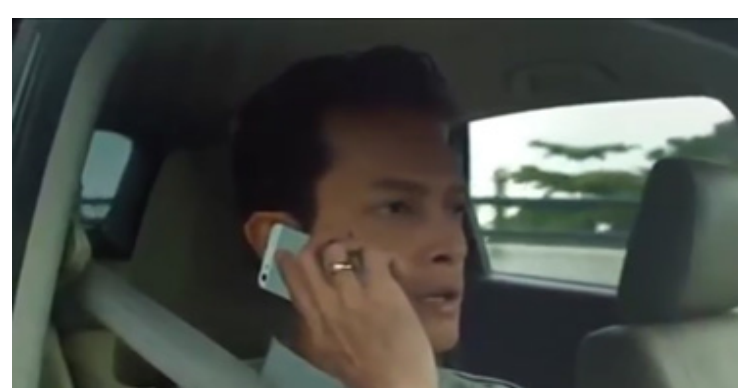

"Kamu kenapa gakngasih kabar mas?", tanya Arini pada Pras dalam telpon. "Maaf sayang, aku bener-bener gak sempet kemaren", jawab Pras. "Kamu dimana sekarang?", tanya Arini lagi. "Menuju Muntilan", jawab Pras. "Aku tunggu sekarang", ucap Arini mengakhiri telpon.

Percakapan melalui handphone saat Pras dalam perjalanan pulang dari rumah sakit. Dalam percakapan itu, dengan terisak Arini menanyakan kabar Pras yang tidak memberinya kabar. Pras tidak begitu saja jujur dengan apa yang dialaminya, lantas ia berucap bahwa pekerjaannya sedang banyak, sehingga ia tidak sempat mengabari keluarganya. Untuk pertama kalinya, Pras berbohong. Namun, ia tidak mungkin mengatakan yang sebenarnya. Dalam benak Pras, ia akan mengatakan yang sesungguhnya di waktu yang tepat.

Secara tersirat, percakapan tersebut merupakan komunikasi interpersonal. Meski tidak secara langsung, namun hal tersebut termasuk kriteria komunikasi interpersonal. Dalam berkomunikasi, diperlukan pula adanya kepahaman situasi dan kondisi komunikan, tepat tidaknya menyampaikan pesan atau informasi saat tersebut. Tidak pantas seorang komunikator jika menyampaikan informasi gembira saat sang komunikan sedang berada dalam situasi yang menyedihkan, hal tersebut justru akan membuat komunikan merasa bertambah kesedihannya dan menjadi emosi.

Menurut Joseph A. Devito dalam bukunya The Interpersonal Communication Book salah satu kualitas umum dalam meraih keefektifan komunikasi adalah 
dengan berempati, yaitu kemampuan seseorang untuk mengetahui yang sedang dialami orang lain pada saat tertentu. Komunikasi empati melalui dua hal, yaitu verbal dan non verbal. Secara non verbal, sikap empati dapat diperlihatkan melalui ekpresi wajah, kedekatan fisik, serta belaian yang sepantasnya.

\section{Gambar 15}

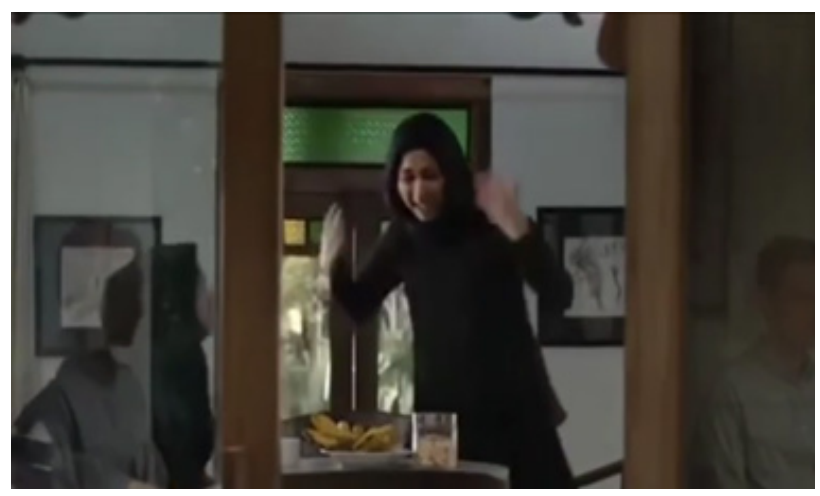

"Rin, Bapak tuh orang baik, dan Ibu tahu apa alasan Bapak", Ibu Arini memulai pembicaraan. Namun, belum selesai berbicara, Arini memutus "Bu, apa menolong orang harus dengan cara menikahinya? Apa gak ada cara lain bu, gak ada jalan lain?", tanya Arini sedikit marah. "Bapak sudah berlaku adil", tambah Ibu Arini. "Adil? Selama 15 tahun menutupi istri keduanya bu, dan melukai hati anaknya, Ibu bilang itu adil? Adil macam apa sih bu? Hal begini mana bisa disebut adil?", bantah Arini.

Ketika ayah Arini meninggal, datang dua orang perempuan yang mengaku sebagai anak dan istri Sutedja, ayah Arini. Seketika, Arini kaget dan menanyakan kebenaran hal tersebut. Dengan nada pelan, Ibu Arini membenarkan kenyataan tersebut. Namun, ia bersikukuh bahwa selama dimadu, ayah Arini selalu bersikap adil terhadap keduanya.
Arini tidak bisa menerima kenyataan pahit tersebut. Selama 15 tahun, ayahnya telah membagi cinta Ibunya dengan orang lain tanpa sepengetahuan Arini. Namun, Arini mempertanyakan keadilan yang dikatakan Ibunya, keadilan seperti apa ketika seorang laki-laki menyembunyikan pernikahan keduanya dengan orang lain selama bertahun-tahun .

Arini berlari menghampiri Pras, dan mempertanyakan kembali ketulusan dan kesetian cinta Pras. Arini merasa terpukul dengan apa yang terjadi terhadap Ibunya, dimadu dengan orang yang tidak pernah ia kenal. Dengan sedikit tertegun, Pras menyembunyikan cincin pernikahannya dengan Meirose, lantas mengamini pernyataan Arini sebagai sebuah jawaban. Pras berpikir, bahwa saat itu bukanlah waktu yang tepat untuk berterus terang kepada Arini mengenai Meirose, karena saat itu jiwa Arini sedang terguncang.

\section{Gambar 16}

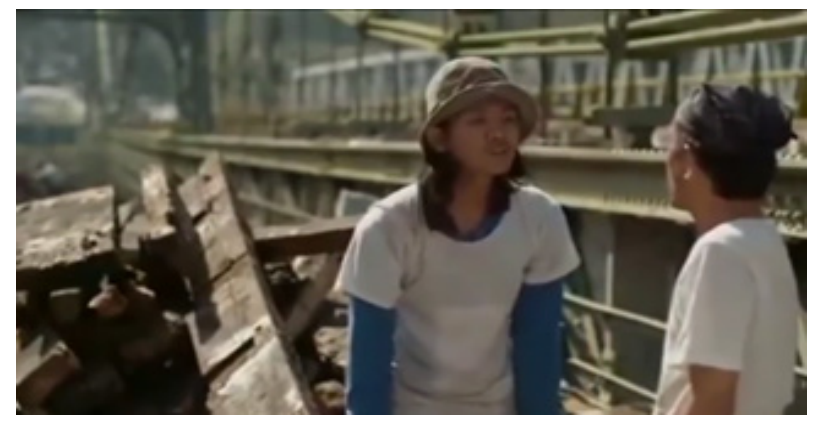

"Buruh bangunan bertopi bertanya, "Eh, poligami kui opo tho?". "Poligami gak ngerti. Iku tho poligami", jawab buruh satunya sambil menunjuk sepeda yang diparkirkan. "Oh, merk pit", respond buruh bertopi mengerti.

Komunikasi sederhana terjadi antara dua buruh bangunan proyek jembatan yang dibangun Pras. Saat itu Amran dan 
Hartono lagi-lagi mempersoalkan poligami Pras. Bagi Hartono, poligami Pras telah menghambat pekerjaan Pras. Di tempat yang sama, buruh bangunan tersebut mendengar pembicaraan merek, dan salah satu buruh bertanya mengenai poligami itu apa. Dengan enteng, buruh lainnya menjawab bahwa poligami adalah merk sepeda, dengan menunjuk kearah sepeda. Tanpa pikir panjang, penanya mengiyakan jawaban tersebut.

Banyak informasi yang dapat diketahui melalui komunikasi, terlebih komunikasi interpersonal. Komunikais interpersonal memiliki banyak kelebihan, diantaranya feedback yang diterima cepat. Dalam percakapan tersebut, jawaban atas pertanyaan yang diajukan berlangsung cepat dan tidak memerlukan biaya layaknya komunikasi melalui handphone. Namun, jawaban tersebut tentulah salah, poligami bukan merk sepeda, akan tetapi memiliki istri lebih dari satu.

\section{Gambar 17}

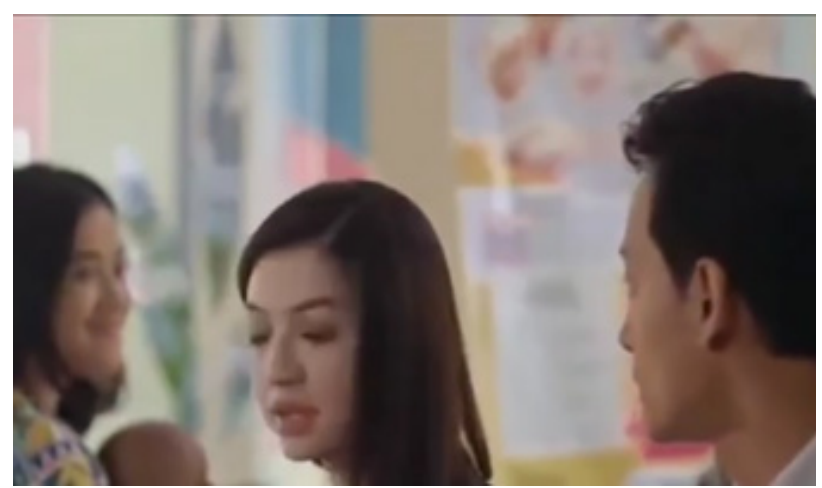

"Maaf, mobilku dipinjem temen gak balikbalik, jadi aku naik ojek", ucap Pras seraya menghampiri Meirose. "Gak apa-apa kok", jawab Meirose dengan senyuman. "Udah dipanggil imunisasi?", tanya Pras pada Meirose. Dengan geleng kepala, Meirose menjawab, "Belum".
Pras menemani Meirose untuk imunisasi Akbar. Dengan sedikit berlari, ia menghampiri Meirose dan duduk di sebelahnya. Pras menyayangi Akbar sebagaimana anaknya sendiri. Perhatian serta kebaikan Pras telah melunakkan hati Meirose. Meirose merasa bahagia Pras telah memilihnya menjadi seorang istri dan ayah dari anaknya, meski ia tahu bahwa ia adalah yang kedua.

\section{Gambar 18}

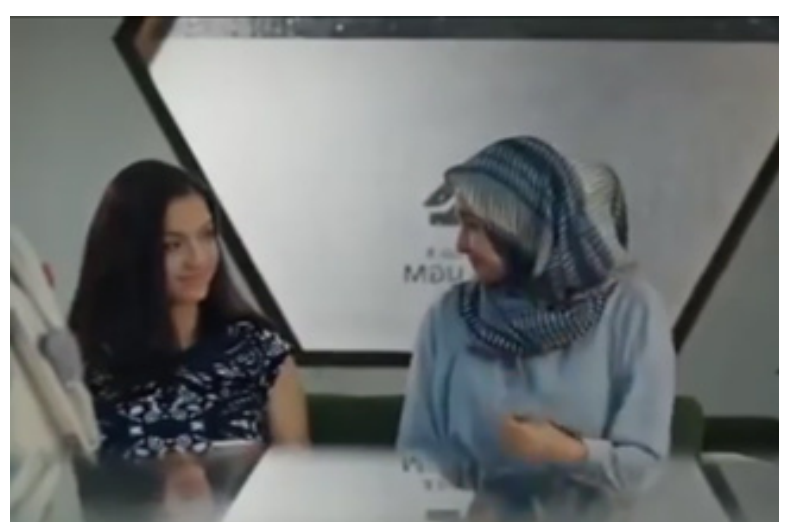

"Saat bertemu, Arini dan Meirose saling tatap dan tersenyum, lalu Arini berucap "Lucu sekali bayinya".

Secara tidak sengaja, Arini bertemu dengan Meirose yang sedang menunggu Pras mengambil uang di ATM. Namun, mereka belum saling mengetahui bahwa mereka adalah madu Pras, sama-sama istri yang telah sah secara agama dinikahi Pras. Dalam pertemuan tersebut, Arini sedikit menyapa Meirose dan Akbar, disambut senyum dari Meirose.

Pertemuan yang tidak terduga menimbulkan komunikasi sederhana antara mereka berdua. Dalam klasifikasinya, percakapan tersebut masuk dalam percakapan sosial, yang mana interaksi masih berlangsung sederhana, karena 
keduanya belum saling mengenal satu sama lain.

Bahasa merupakan alat verbal yang digunakan seseorang sebagai komunikasi tentunya memiliki peranan penting. Dengan menggunakan bahasa, seseorang dapat berinterkasi, sosialisasi dan berkomunikasi dengan pihak lain. Namun, selain bahasa, komunikasi juga dapat berupa non verbal, misal tulisan. Akan tetapi, bahasa merupakan alat yang paling efektif dalam berkomunikasi.

Komunikasi interpersonal sangat penting dilakukan untuk mendukung kelancaran berorganisasi, kerja dan menjalani hidup. Komunikasi yang dsertai hubungan baik akan meminimalisisr kesenjangan dari berbagai pihak dan mengurangi adanya pertikaian yang terjadi. Komunikasi yang baik merupakan mediator dalam transformasi pesan atau informasi untuk pihak lain dalam mendukung kerjasama atau kepentingan lain.

Gambar 19

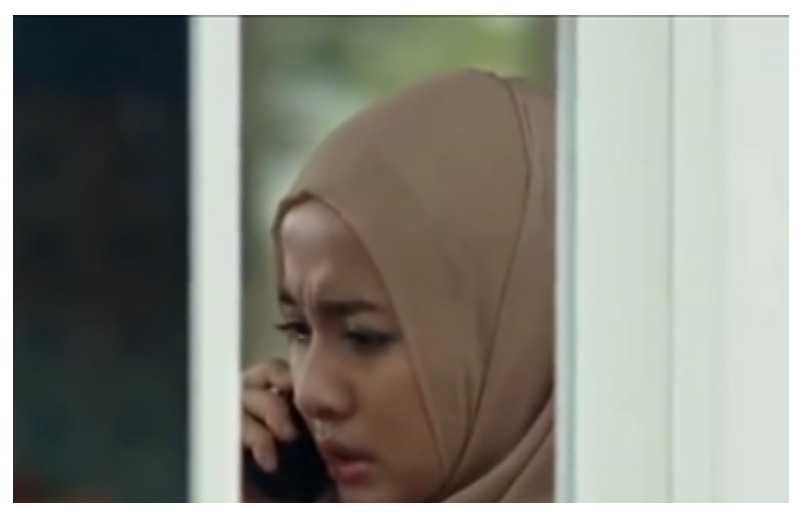

"Selamat pagi, maaf mengganggu mbak. Saya mau tanya, apa ada obat untuk Akbar Muhammad Prasetya dari dokter Anita Ekowati?", tanya Arini pada petugas apotek yang tertulis dalam nota. "Maaf, mbak dari mana ya?", tanya balik sang petugas apotek. "Dari apotek mbak. Kemaren obatnya ada yang kurang, nah rencananya hari ini mau saya kirim. Bisa minta tolong minta alamat dan nomor rumahnya mbak?", jawab Arini. "Sebentar ya mbak", pinta petugas apotek.

Arini menemukan nota pembelian obat milik Pras yang ditemukan di kantong celananya. Mencurigai hal tersebut, Arini menelpon Contact Person (CP) yang tertera dalam nota tersebut. Dengan mengaku sebagai pegawai apotek, Arini minta nomor handphone dan alamat rumah Meirose. Dengan segera, untuk membuktikan kekhawatirannya, Arini menelpon rumah Meirose, dan betapa terkejutnya ia ketika Pras yang mengangka telpon tersebut.

Di seberang telepon, Meirose bertanya kepada Pras mengenai siapa yang menelpon, namun Pras menjawab bahwa tidak ada jawaban suara. Bibir Arini kelu, tak mampu berkata sepatah katapun. Pras yang selama ini ia agungkan ternyata telah mengkhianatinya, mengulang kembali kisah pengkhianatan yang telah ayahnya lakukan semasa hidup.

Sebuah nota telah mengungkap segala kebenaran yang ada. Melalui nota pembelian, Arini sadar bahwa selama ini Pras telah berkhianat, membagi cintanya dengan orang lain tanpa sepengetahuannya.

Aspek kepercayaan yang selama ini Arini yakini telah luluh lantak, keputusan Pras untuk membagi cintanya telah membuat Arini lemah, rapuh. Ia merasa teramat kecewa dengan lelaki yang telah memberinya satu anak tersebut. Ia tak habis pikir mengapa Pras dapat melakukan hal jahat tersebut. 


\section{Gambar 20}

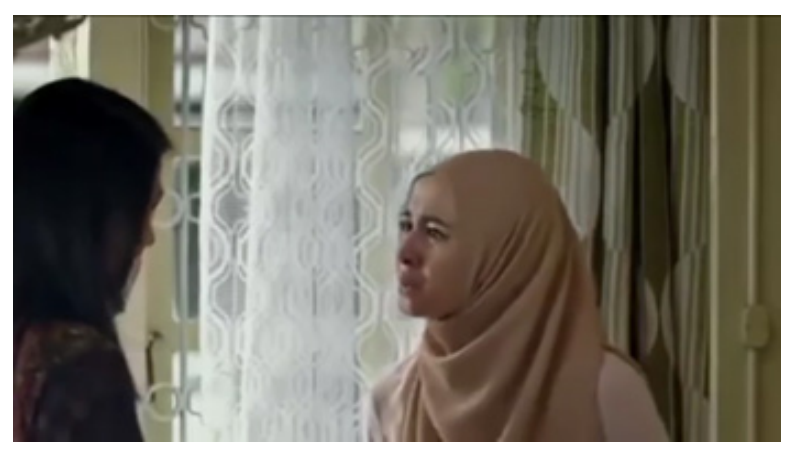

"Sudah berapa lama kalian menikah?", tanya Arini membuka percakapan. "Sejak Akbar lahir", jawab Meirose singkat. "Apa? Jadi, selama ini kamu dan suamiku berzina?", tuduh Arini. "Bukan seperti itu mbak, Akbar bukan darah daging mas Pras", Jelas Meirose. "Apapun itu, pada kenyataannya kamu telah menikah dengan suamiku", ucap Arini marah. Meirose mencoba menjelaskan, "Gini ya mbak, mas Pras telah menghentikan usaha saya bunuh diri. He safe my life. Dan sekarang dia mengajarkan saya agama". "Dengan cara menikahi kamu? Iya? Hebat kamu, hebat kamu..!!!", pungkas Arini marah berlalu pergi.

Untuk meyakinkan hati dan pikirannya, Arini mendatangi rumah Meirose. Disana, ia mendapati gambar suaminya yang sedang berduaan dengan Meirose. Hatinya serasa panas bagai api berkobar. Dengan suara yang tertahan, Arini menanyakan pernikahan Pras, suaminya dengan Meirose. Meirose pun menceritakan yang sebenarnya, bahwa Pras menikahinya atas dasar menolong dan menyelamatkan hidupnya. Segala hal ia curahkan kepada Arini, bahwa ia hanya hidup sebatang kara, dan Pras datang sebagai penyelamat hidupnya. Mendengar pengakuan tersebut, Arini marah. Ia tidak bisa menerima alasan Meirose, ia menganggap Meirose telah menghancurkan dongeng yang telah dibangunnya bersama Pras hanya untuk menghidupkan dongeng Meirose.

Saat itu Arini sedang dalam puncak emosinya, ia tidak dapat berpikir jernih. yang ada dalam pikirannya saat itu adalah Meirose telah menjadi penghancur rumah tangganya. Nada tinggi yang diucapkan Arini membungkam Meirose.

Gambar 21

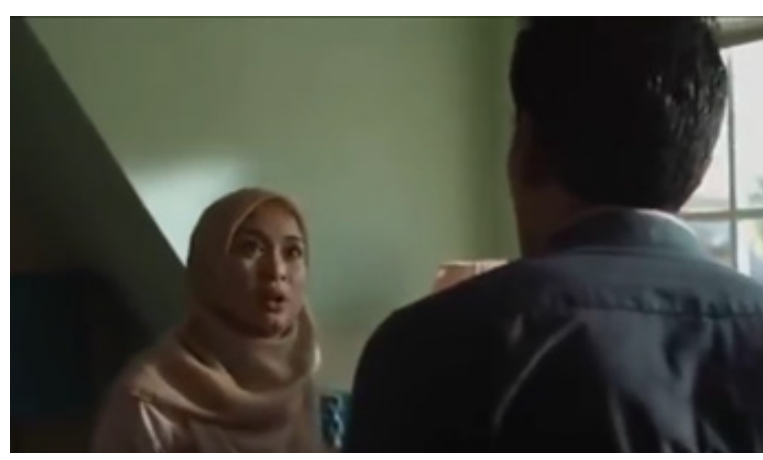

"Rin...", panggil Pras. "Tega kamu mas", balas Arini. "Aku bisa jelasin semua ini", harap Pras. "Kamu sudah janji mas, jangan pegang aku. Pergi....", pinta Arini pada Pras. "Rin, dengerin dulu penjelasanku Rin...", pinta Pras pada Arini. "Enggak...pergi kamu", usir Arini.

Pengkhinatan Pras atas ketulusan cinta yang diberikan Arini, membuat Arini marah besar. Baginya, poligami yang telah dilakukan Pras telah menghancurkan surga cinta yang telah dibangun selama bertahuntahun. Kehadiran perempuan lain telah mengiris-iris hati dan jiwa Arini.

Pras tidak dapat membendung kemarahan Arini. Ia menyadari bahwa pangkal dalam masalah rumah tangganya adalah dirinya sendiri. Ia mencoba berulang kali menjelaskan, namun Arini tidak bisa menerimanya. Bagi Arini, Pras telah melukai hatinya, membagi cinta dan 
perhatiannya dengan orang lain.

Memiliki latar belakang sosial yang sama membuat Pras memantapka diri menyelamatkan Meirose, meski dengan cara menikahinya. Saat itu, tujuan utamanya hanyalah menolong seseorang yang akan bunuh diri. Namun, kenyataan tersebut dilihat lain oleh Arini. Untuk meredam emosi, Pras memutuskan diri untuk keluar dari rumah, surga dunia yang ia bangun bersama Arini dan Nadia.

Pertikaian dalam rumah tangga biasa terjadi, entah karena hal sepele, salah paham atau masalah besar. Untuk mengatasi masalah tersebut, komunikasi yang baik menjadi jalan keluar, akan tetapi jika tidak berhasil, berpikir dingin dengan menenangkan pikiran menjadi hal yang mudah diambil. Saat itu, Pras memilih pisah rumah dengan Arini sebagai bentuk penyelesaian masalah. Ia berharap dengan begitu Arini dapat menenangkan pikiran dan dapat berpikir jernih.

\section{Gambar 22}

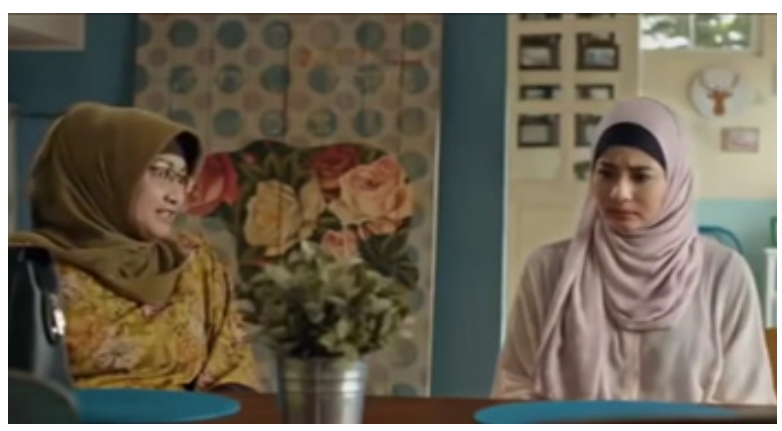

"Sudah berapa lama Pras tidak pulang?", tanya Ibu Arini pada anaknya. "Ibu tahu darimana?", tanya Arini heran. "Ibu tahu kekecewaanmu, tapi tidak ada masalah yang tidak dapat terselesaikan, agama mengajarkan kita untuk menghadapi masalah dengan sabar dan ikhlas ", nasihat
Ibu Arini. "Apa perempuan dilahirkan hanya untuk mengikhlaskan hati kita disakiti bu? Arini tidak sekuat Ibu", jawab Arini. "Ibu juga tidak ingin kamu menjadi seperti Ibu, tapi ada hal yang harus kamu pikirkan, masa depan Nadia", Ibu Arini mengingatkan. "Banyak kisah anak yang sukses dari keluarga single parent", balas Arini. "Astagfirullahaladzim....", ucap Ibu Arini. "Dongeng madani yang Arini bangun bersama mas Pras telah hancur", tambah Arini. "Ibu tahu itu. Tapi, dongeng itu belum berakhir", ucap Ibu Arini kembali mengingatkan.

Mengetahui apaa yang terjadi dengan Arini, Ibu Sulastri memberikan dukungan moril kepada anaknya. Memberikan wejangan yang dapat menenangkan hati Arini. Sebagai seorang Ibu dan pernah dimadu pula cintanya, tentu ia merasakan pula apa yang dirasakan Arini, anaknya. Ibu berpikir, bahwa ikhlas merupakan obat sakit hatinya, mengingat masa depan Nadia yang masih panjang.

Arini berontak dengan saran Ibunya tersebut, ia berpikir apakah perempuan harus selamanya mengalah dan ikhlas melepaskan seseorang yang disayanginya. Sejak pernikahan kedua suaminya, Sulastri berusaha untuk mengikhlaskannya, namun tidak begitu dengan Arini. Ia merasa bahwa dongengnya telah berkahir, mati.

Tujuan komunikasi interpersonal adalah mengubah sikap dan perilaku. Disini, Ibu Arini mencoba untuk mengubah pikiran Arini, ia berharap Arini bisa mengikhlaskan peristiwa yang telah terjadi di hidupnya. 


\section{Pesan Dakwah dalam Film "Surga yang Tak Dirindukan"}

"Surga yang Tak Dirindukan" merupakan sebuah film yang bergenre Islami, mengangkat kisah yang kadang beberapa orang alami. Kisahnya yang menyentuh, membuat setiap adegannya termemori di pikiran. Selain kisah yang mengharu biru, terdapat pula banyak ibrah (pelajaran) yang dapat diambil dan dijadikan sebuah pijakan dalam bertindak. Berikut pesan-pesan dakwah yang termuat dalam film "Surga yang Tak Dirindukan":

a) Menolong orang yang membutuhkan

Gambar 23

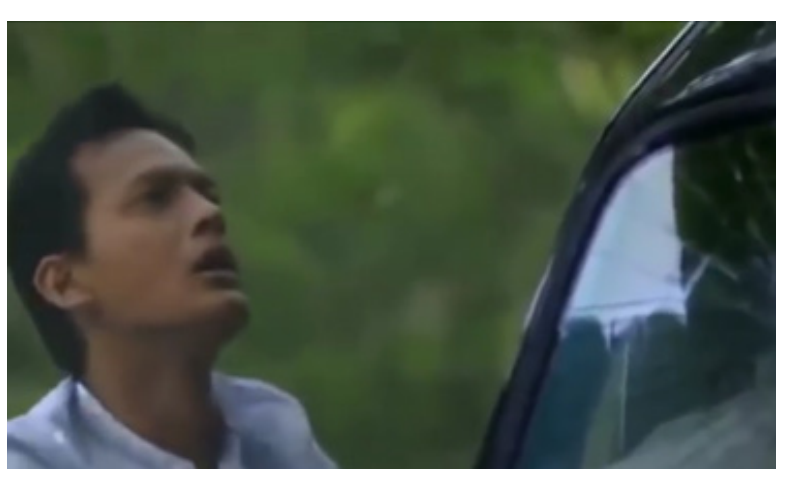

"Tolong...tolong...", teriak Pras meminta pertolongan.

Jiwa penolong terlihat saat Pras di perjalanan. Ia melihat sebuah mobil yang masuk jurang. Dengan cepat dan sigap, Pras menyusuri Jurang dan menyelamatkan pengemudi mobil. Karena tidak ada orang lain selain dirinya, Pras membantu korban kecelakaan tersebut sendirian dan membawanya berobat ke rumah sakit.

\section{Gambar 24}

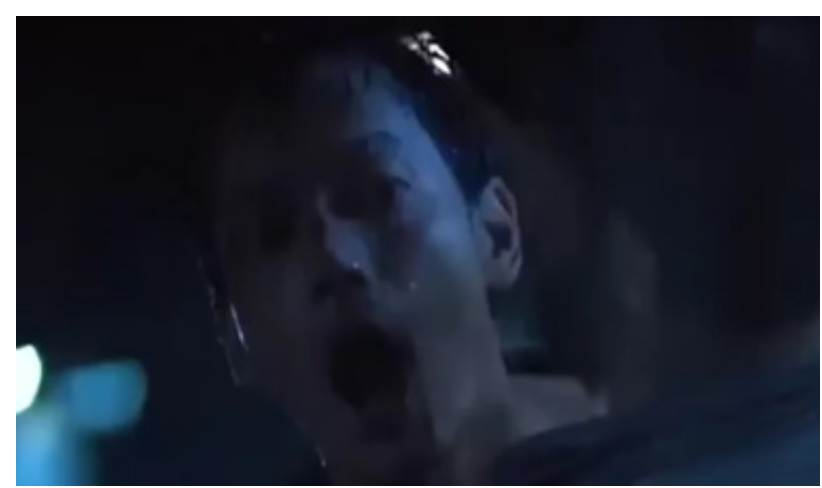

"Lari, cepat lari kamu", teriak Pras pada seorang perempuan yang menjadi korban. Seketika terdapat tiga kawanan perampok, dan menghajar Pras. Pras tidak dapat melawan, dan akhirnya salah satu perampok tersebut menusuk Pras dengan sebilah pisau di bagian perutnya.

Sifat penolong Pras juga terlihat saat ia menolong seorang wanita di kegelapan malam dari perampok. Meski pada akhirnya, ia dibawa ke rumah sakit karena ditusuk oleh para perampok tersebut. Tanpa memikirkan keselamatan dirinya, Pras menolong orang yang membutuhkan bantuan, tanpa pamrih dan minta imbalan.

b) Menjadi imam yang baik

\section{Gambar 25}

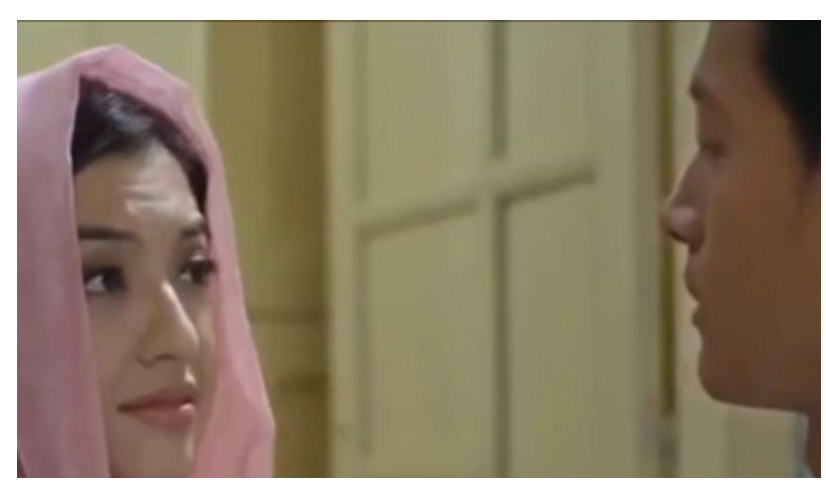


"Kamu suruh aku pakai ini?", tanya meirose pada pras sembari melihat pemberian Pras. "Huum", jawab Pras singkat, lalu memakaikan jilbab pada Meirose. "Bulet?", tanya Meirose pada Pras. "Gak, kamu cantik banget Pake hijab.", jawab Pras terpukau. "Apa setiap perempuan muslim harus pakai hijab?", tanya Meirose. "Iya", respon Pras. "Kenapa dilepas?", tanya Pras pada Meirose saat ia melepaskan jilbabnya. "Masak di rumah pakai jilbab", jawab Meirose. Lalu Meirose memberikan buku tuntunan shalat pada Pras, seketika Pras bertanya, "Kenapa?". "Kan kamu imamku, kamu yang ngajarin aku, oke?", jawab Meirose. "Oke", ucap Pras terheran.

Usai menikahi Meirose, Pras memberikan Jilbab dan buku panduan shalat untuk Meirose. Pras berharap dengan begitu Meirose dapat menjalani hidup yang baik. Melalui perlakuan tersebut, mengindikasikan bahwa Pras telah menjadi imam yang baik, mampu membawa istrinya ke jalan benar. Menyarankan Meirose untuk menggunakan hijab dan melaksanakn shalat.

c) Menjadi Ibu yang baik

\section{Gambar 26}

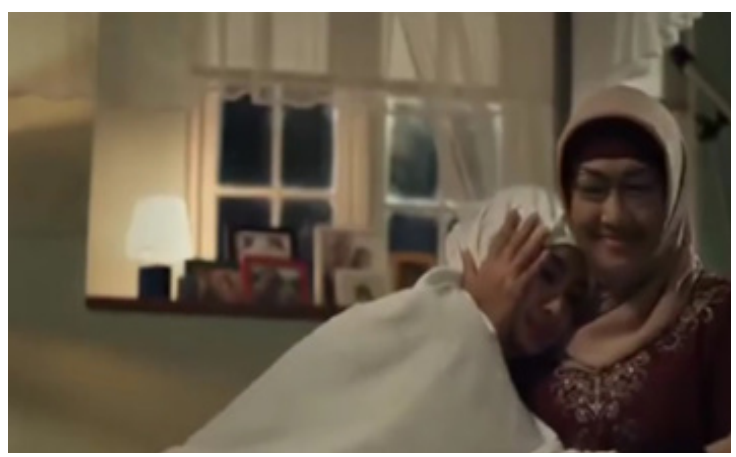

"Sebenernya Ibu menyikas diri Ibu sendiri", ucap Arini pada Ibunya. "Ibu tidak tahu apa yang terjadi, jika Ibu mengambil keputusan yang sebaliknya. Selama kamu sehat, selama kamu tidak kekurangan sesuatu apapun, segala yang sulit terasa lebih ringan", jawab Ibu Arini dengan tenang. "Ibu sudah memilih, mengikhlaskan dan mema'afkan. Ibu tidak ingin kamu tumbuh dalam kebencian Ibu sama Bapak. Kamu punya pilihan sendiri Arini, tapi apapun yang menjadi pilihan kamu sebaiknya kamu tabayyun dulu dengan Pras", nasihat Ibu Arini pada anaknya.

Sulastri, sebagai Ibu selalu mendampingi Arini saat ia menghadapi masalah. Dengan sabar dan lemah lembut, Sulastri memberikan nasihat dan saran untuk anaknya. Menjadi Ibu yang baik, menimbulkan jiwa keIbuan yang baik pula dalam diri Arini.

d) Menjadi istri yang setia

Gambar 27

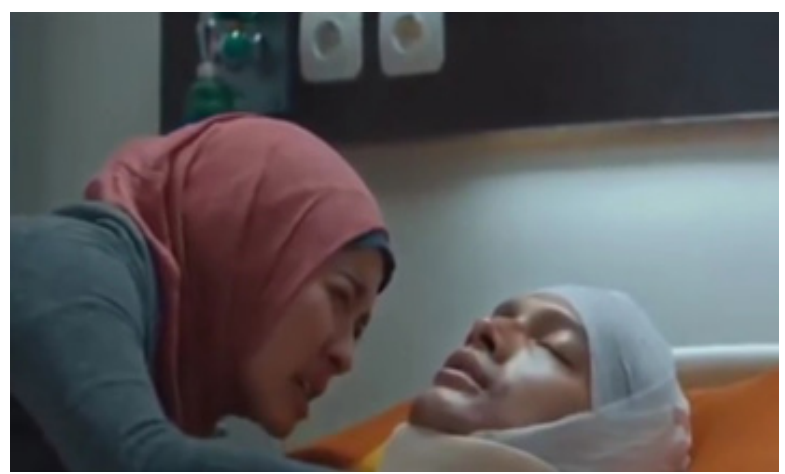

"Mas, ini aku Arini mas. Kamu harus kuat, kamu harus kuat mas", ucapa Arini, berharap Pras bisa segera sadar.

Ketika Pras dirawat di rumah sakit, Arini mendampingi Pras dengan sepenuh hati. Ia menyayangkan yang terjadi kepada Pras. Menolong orang lain dan mengorbankan dirinya sendiri. Kesetian Arini teruji ketika Pras sakit. Namun, Arini tetap merawat dan menunggu Pras dengan sabar, sebagai istri yang baik dan setia bagaimanapun kondisinya. 
e) Tetap bersikap baik di depan anak, meski sedang dalam pertikaian

Gambar 28

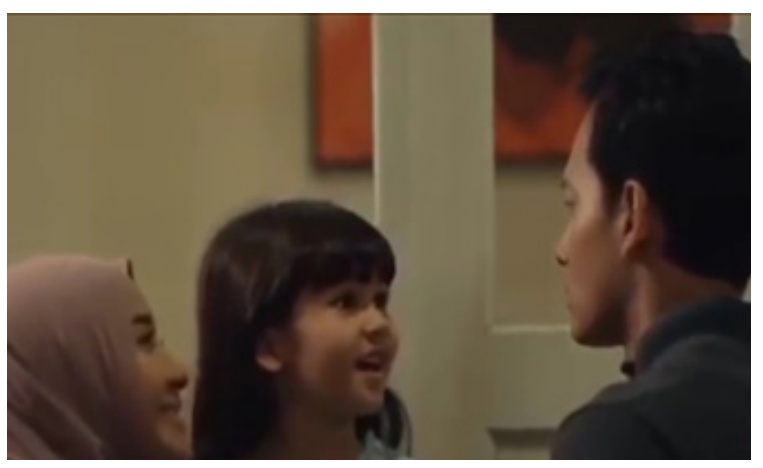

"Ayah", panggil Nadia pada Pras yang saat itu keluar dari rumah. Menghampiri Nadia, Pras bertanya, "Tuan putri kenapa bangun?". "Ayah mau pergi ya?", tanya balik Nadia pada Pras. "Kalau ayah dan bunda marahan, nanti Nadia gak punya adek kecil", tambah Nadia. "Nadia, bunda sama ayah gak lagi marahan kok", ucap Arini dari balik pintu. Menghampiri Nadia dan Pras, Arini menambahkan, "Nadia, ayah malam ini gak akan kemana-mana. Ayah disini nemenin tuan putri kecil". "Bener yah?", tanya Nadia pada ayahnya. Pras menengok ke arah Arini, dan menjawab, "Iya sayang ayah gak akan kemana-mana". "Yes, hore...!!! akhirnya sang raja gak jadi pergi. Ayo masuk", ucap Nada girang seraya menggandeng tangan Arini dan Pras.

Meski dalam pertikaian, namun Pras dan Arini tidak sedikitpun menampakkan pertikaian tersebut di depan Nadia. Di depan Nadia, mereka bersikap baik dan harmonis, seakan tidak terjadi apa-apa. Arini tetap menyunggingkan senyum kepada Pras saat Nadia meminta tidur bersama. Nadia berpikir bahwa orang tuanya dalam kondisi bak-baik saja.

Anak kecil seharusnya memang tidak perlu mengetahui permasalahan yang dialami orang tuanya, karena hal tersebut dapat mengganggu psikis anak. Orang tua sebaiknya tidak bersikap kasar, atau menampakkan pertengkaran dengan pasangan di depan anak. Anak kecil ibarat kertas putih, apapun yang ditulis di atasnya akan tertuang dan selanjutnya akan ditiru oleh sang anak.

f) Menjadi pribadi yang ikhlas

Ikhlas tentu bukan perkara yang mudah. Butuh keyakinan dan kepercayaan dalam menumbuhkan sikap ikhlas. Sedikit sekali orang yang dapat bersikap ikhlas, tak terkecuali Arini. Saat pertama kali mengetahui Pras menikah lagi, ia marah besar dan tak dapat mengikhlaskannya. Namun, seiring berjalannya waktu, Arini dapat mengikhlaskannya.

\section{Gambar 29}

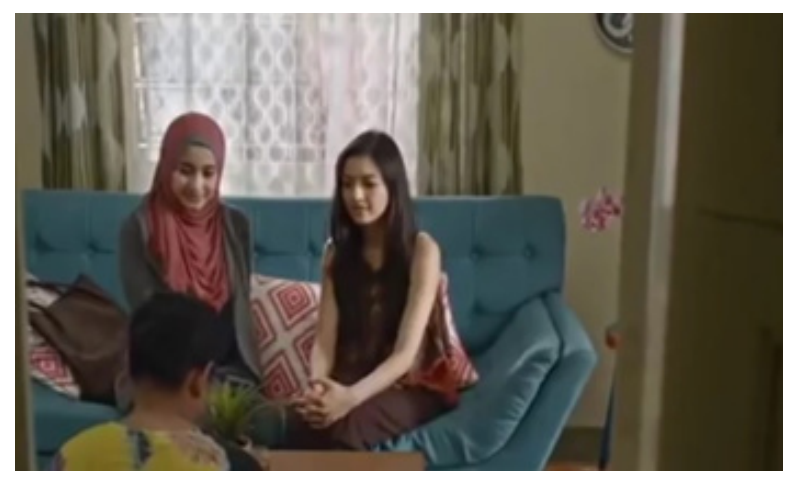

"Ini orang tua kamu?", tanya Arini pada Meirose saat memandangi foto yang tertempel di dinding. "Iya", jawab Meirose. "Papaku pergi saat aku ulang tahun yang ke-12, dan mamaku bunuh diri. Sejak saat itu, aku tinggal sendirian, dan sama mbok", tambah Arini seraya mempelkenalkan mboknya pada Arini. "Trus, sekarang papamu dimana?", tanya Arini lagi. "Papaku sekarang di Jakarta, bersama keluarga barunya. Dia lumpuh.", jawab Meirose. Meminum seteguk airnya, lalu Meirose bertanya balik, "Gimana mbak, 
ada apa?", dengan senyum yang tersungging di bibir. "Aku datang kesini karena mas Pras memintamu datang ke rumah sakit membawa Akbar", jawab Arini menjelaskan. "Mbak, aku harusnya gak ada disana. Gak ada di kehidupan mbak Arini dan mas Pras", ucap Meirose terkejut. "Semua sudah terjadi Mei, sekarang kita fikirkan gimana caranya menjalani hidup kita ke depan. Unutuk Akbar, untuk Nadia", jelas Arini. "Kenapa mbak melakukan ini?", tanya Meirose heran. "Hidup itu pilihan, dan ini adalah pilihanku", jawab Arini bijak. "Ayo Mei, sekarang kita ke rumah sakit, dan jangan lupa kamu ngajak Akbar. Aku tunggu disini ya", ucap Arini pada Meirose, mengalihkan perhatian.

Sikap ikhlas Arini terlihat ketika ia mendatangi rumah Meirose untuk mengajaknya menjenguk Pras bersamasama. Dengan nada lembut dan sopan, Arini meminta Meirose untuk bersiap-siap. Selanjutnya, Arini juga mengajak Akbar ikut serta. Sikap Arini telah bersahabat dengan Meirose. Bagi Arini, Meirose adalah adiknya.

Tentu bukan perkara mudah untuk ikhlas, namun demi kesembuhan Pras, Arini ikhlas melakukannya. Secara lisan, Arini tak mengungkapkan keikhlasannya berbagi suami, namun sikap dan tindakannya mengindikasikan bahwa ia telah ikhlas.

g) Menjadi orang yang lebih baik dari sebelumnya

\section{Gambar 30}

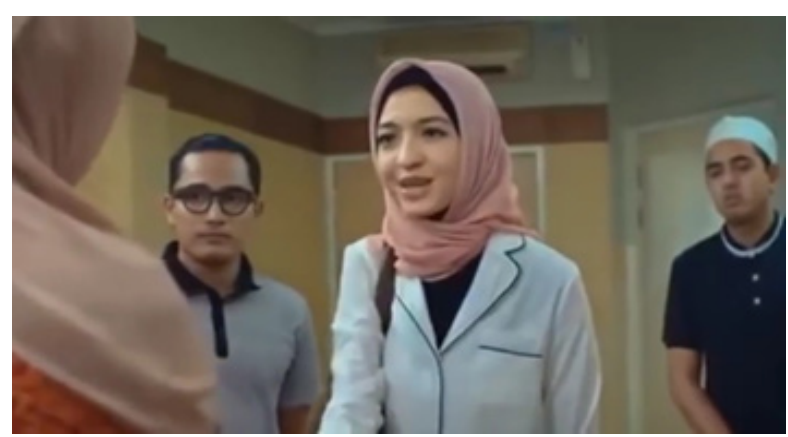

Setelah menikah dengan Pras, Meirose perlahan menjadi pribadi yang baik. Ia mulai sholat, mengaji dan mengenakan hijab. Bagi Meirose, Pras adalah imam yang baik, mampu membawanya pada hidayah Allah dan menjadikannya perempuan yang baik.

h) Baik hati

\section{Gambar 31}

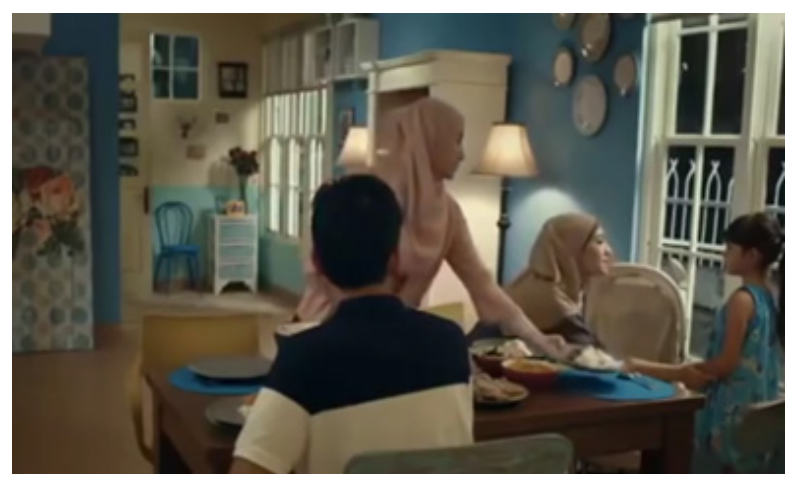

"Tante Mei, malem ini nginep ya, biar Nadia bisa main bareng dedek Akbar", pinta Nadia pada Meirose. "Dedek Akbar nya aja ya yang main, tante Mei pulang. Ntar yang jagain rumah tante Mei siapa?", jawab Meirose. "Gak mau, Nadia mau dongengin putri Sabrina sama tante Mei", ujar Nadia. "Bosen ah, dongengnya itu-itu terus", ucap Pras ikut menimbrung. "Kali ini beda. Kali ini putri Sabrina berteman dengan peri yang baik banget. Mau ya, mau ya tante Mei, pliss..", harap Nadia. "Ya udah, sekarang Nadia dudukdulu, makan yang banyak. Nanti selesai makan, bunda siapin kamar buat tante Mei", ucap Arini menengahi pembicaraan. "Yee...!!!", teriak Nadia senang.

Arini merupakan perempuan yang baik, terlihat ketika ia menyarankan Meirose memberikan obat pada Akbar yang sedang sakit, meski ia sadar bahwa saat itu Meirose adalah madunya. Selanjutnya, saat Meirose bersama Akbar betandang ke rumah Arini. 
Di sana, Arini menjamu Meirose dan memperlakukannya dengan baik sebagai tamu dan menganggapnya sebagai adik. Atas saran Nadia, Arini memperbolehkan Meirose dan Akbar menginap di rumahnya. Melakukan shalat berjamaah bersama Meirose dan Pras, tak menodai hati Arini sedikitpun untuk marah atau kecewa kepada Meirose, ia malah menyambutnya dengan bahagia.

i) Kebesaran hati untuk mengalah

\section{Gambar 32}

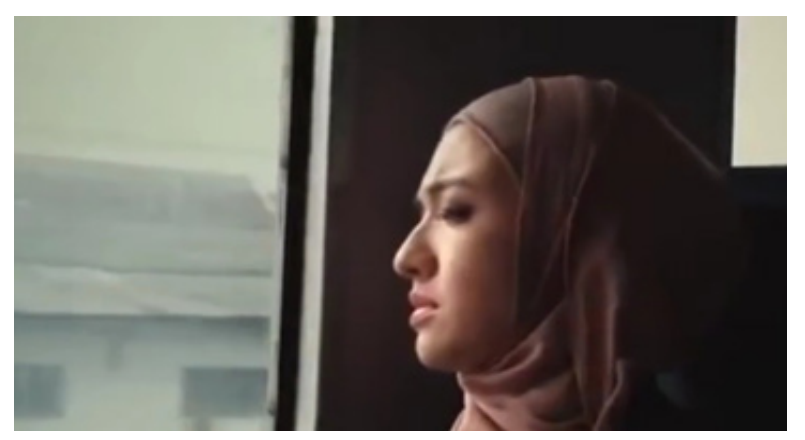

"Hari ini, aku tutup dongengku dengan kesedihan, agar dongeng wanita lain berakhir dengan kebahagiaan. Karena buatku, kebahagiaan adalah ketika kita bisa membuat orang lain bahagia".

Meirose memutuskan pergi dari kehidupan Pras dan Arini, mencoba mengalah untuk tak merusak kebahagian Arini yang selama ini telah ia sakiti dengan kehadirannya. Ia tidak ingin mengorbankan Pras dan Arini. Meirose menyadari bahwa selama ini yang dilakukan telah menyakiti perempuan lain. Dengan besar hati, Meirose pergi, berharap dongeng Arini dapat berlanjut bahagia.

\section{SIMPULAN}

Berdasarkan pembahasan di atas, maka kesimpulan dari kajian Studi Analisis Pola Komunikasi Interpersonal dalam Film "Surga yang Tak Dirindukan" Karya Kuntz Agus Tahun 2015 adalah sebagai berikut:

1. Komunikasi interpersonal yang dipakai para pemain "Surga yang Tak dirindukan adalah diadic communication, yaitu komunikasi yang terjadi antara dua orang. Dalam diadic communication, terdapat dua jenis komunikasi yang digunakan, yaitu primer dan sekunder. Secara primer terlihat ketika Komunikasi terjadi secara langsung (face to face) dan sekunder ketika komunikasi terjadi melalui media/perantara. Namun, kadang pula memakai jenis triadic communication, yakni komunikasi yang terdiri dari tiga orang. Klasifikasi komunikasi interpersonal yang tergambar dalam film "Surga yang Tak Dirindukan" berupa interaksi intim, karena antara komunikator dan komunikan memiliki ikatan emosional yang kuat.

2. Terdapat banyak muatan Islami dalam film "Surga yang Tak Dirindukan", diantaranya sebagai berikut: menolong orang yang membutuhkan; (2) menjadi imam yang baik; (3) menjadi ibu yang baik; (4) menjadi istri yang setia; (5) keikhlasan; (6) kebesaran hati untuk mengalah. 


\section{DAFTAR PUSTAKA}

Aw, Suranto, Komunikasi Interpersonal, Yogyakarta: Graha Ilmu, 2011.

Basrowi dan Suwandi, Memahami Penelitian Kualitatif, Jakarta: PT. Rineka Cipta, 2008. Bungin, Burhan, Sosiologi Komunikasi, Jakarta: Kencana Prenadamedia Group, 2014.

Effendy, Onong Uchjana, Ilmu, Teori dan Filsafat Komunikasi, Bandung: PT Citra Aditya Bakti, 2003.

Malaki, Ekky, Why Not: Remaja Doyan Nonton: Seri Penuntun Remaja, Bandung: Mizan Uyana Kreatif, 2004.

Muhammad, Arni, Komunikasi Organisasi, Jakarta: Bumi Aksara, 2013.

Mulyana, Deddy, Nuansa-Nuansa Komunikasi: Meneropong Politik dan Budaya Masyarakat Kontemporer, Bandung: PT Remaja Rosdakaraya, 1999. Movie.co.id/surga-yang-takdirindukan.

Rakhmat, Jalaluddin, Psikologi Komunikasi, Bandung: Remaja Rosdakarya, 2008.

Riswandi, Ilmu Komunikasi, Jakarta: Graha Ilmu, 2009.

Vivian, John, Teori Komunikasi Massa, Jakarta: Kencana, 2008.

Wood, Julia T., Komunikasi Teori dan Praktik, Jakarta: Salemba Humanika, 2013. 